\title{
Trimodal Rescue of Hind Limb Ischemia with Growth Factors, Cells and Nanocarriers: Fundamentals to Clinical Trials
}

\begin{tabular}{|r|l|}
\hline Journal: & Canadian Journal of Physiology and Pharmacology \\
\hline Manuscript ID & cjpp-2016-0713.R1 \\
\hline Manuscript Type: & Review \\
\hline Date Submitted by the Author: & 12 -Jan-2017 \\
\hline Complete List of Authors: & $\begin{array}{l}\text { Laksmanan, Rajesh; University Of Connecticut Medical Center, Surgery } \\
\text { Ukani, Gopi; University of Connecticut Medical Center, Surgery } \\
\text { Rishi, Muhammad; University of Connecticut Medical Center, Surgery } \\
\text { Maulik, Nilanjana; Univ. of Connecticut Medical Center, Surgery }\end{array}$ \\
\hline Keyword: & $\begin{array}{l}\text { Peripheral artery disease, Critical limb ischemia, Growth factors, Gene } \\
\text { therapy, Nanocarriers }\end{array}$ \\
\hline
\end{tabular}




\title{
Trimodal Rescue of Hind Limb Ischemia with Growth factors, Cells and Nanocarriers: Fundamentals to Clinical Trials
}

\author{
Rajesh Lakshmanan, Ph.D, Gopi Ukani, M.D, Muhammad Tipu Rishi, M.D, \\ Nilanjana Maulik, Ph.D, FAHA
}

Molecular Cardiology and Angiogenesis Laboratory, Department of Surgery, University of Connecticut Health, Farmington, CT, USA

Running Title: Trimodal Rescue of Hind Limb Ischemia: Fundamentals to Clinical Trials

\#Corresponding author:

Nilanjana Maulik, Ph.D., FAHA,

Molecular Cardiology and Angiogenesis Laboratory,

Department of Surgery

University of Connecticut School of Medicine

263, Farmington Avenue, Farmington, CT, USA

E-mail: nmaulik@uchc.edu 


\begin{abstract}
Peripheral Artery Disease is a severe medical condition commonly characterized by critical or acute limb ischemia. Gradual accumulation of thrombotic plaques in peripheral arteries of the lower limb may lead to intermittent claudication or ischemia in muscle tissue. Ischemic muscle tissue with lesions may become infected, resulting in a non-healing wound. Stable progression of the non-healing wound associated with severe ischemia might lead to functional deterioration of the limb, which, depending on the severity, can result in amputation. Immediate rescue of ischemic muscles through revascularization strategies is considered the gold standard to treat critical limb ischemia. Growth factors offer multiple levels of protection in revascularization of ischemic tissue. In this review, the basic mechanism through which growth factors exert their beneficial properties to rescue the ischemic limb is extensively discussed. Moreover, clinical trials based on growth factor and stem cell therapy to treat critical limb ischemia are considered. The clinical utility of stem cell therapy for the treatment of limb ischemia is explained and recent advances in nanocarrier technology for selective growth factor and stem cell supplementation are summarized.
\end{abstract}

Keywords: critical limb, growth factors, ischemia, nanocarriers, stem cell therapy 


\section{Introduction:}

\section{Peripheral Artery Disease (PAD) and clinical management}

PAD is a severe pathological disorder that arises due to blockage of arteries by thrombosis in the lower limbs. PAD is characterized by intermittent claudication or critical ischemia and is objectively identified by an ankle-brachial index $[\mathrm{ABI}]<0.9$ (Jude et al. 2010). In the United States approximately 8 million people suffer from PAD, and $12 \%$ to $20 \%$ of these patients are aged 60 years or older (Roger et al. 2011). Numerous risk factors are associated with PAD including, but not limited to, age, gender, race, and unhealthy lifestyle conditions such as smoking, hypertension, diabetes mellitus, dyslipidemia, increased levels of C-reactive peptide (CRP), hyperviscosity, chronic renal insufficiency, and hypercoagulable syndrome (Norgren et al. 2007). PAD by itself, is a progressive disease. There is a continuous deterioration of functional disability in patients suffering from either symptomatic or asymptomatic disease (Roger et al. 2011). With regard to intermittent claudication, around $7 \%$ of patients require vascular bypass surgery, and 4\% will eventually require limb amputation (Weitz et al. 1996). Lower limb amputation, in general, is associated with extensive injury and death. Only 50\% of patients can ambulate after a below-knee amputation (BKA) (Isner et al. 1995). In addition, 5\% to $10 \%$ of patients die during the perioperative period after BKA. This number rises by $15 \%$ to $20 \%$ for an above-knee amputation (AKA) (Isner et al. 1995). Approximately $40 \%$ of patients die after undergoing the first major amputation (Isner et al. 1995). PAD is associated with adverse cardiovascular and cerebrovascular events. About $20 \%$ of PAD patients experience a non-fatal cardiovascular event over the course of 5 years. The estimated mortality during this 5 year period is $30 \%$ (Weitz et al. 1996). 
Based on symptoms, PAD can be classified at an acute or chronic level occlusion level, and occurrence of infection (Anderson et al. 2013). The practice guidelines set forth by the American Heart Association (AHA) classify PAD according to 4 major levels: 1) an asymptomatic stage; 2) a claudication stage; 3) a critical limb ischemia (CLI) stage; and 4) an acute limb ischemia (ALI) stage (Anderson et al. 2013). The asymptomatic stage involves walking impairment, with an $\mathrm{ABI}>1.30$. The claudication stage involves the occurrence of pain in the lower limb, especially in calf muscles during exercise. The CLI stage is characterized by chronic pain along with ischemic lesions. Patients with diabetic conditions, neuropathy, and renal failure are at high risk for CLI. At the ALI stage surgical intervention is frequently required to reestablish vascularization in the limbs (Hardman et al. 2014). Separate from the classification by AHA, numerous clinical trials follow Rutherford's classification of CLI or ALI for treating patients. Whereas, ALI has been classified at 3 levels: 1) viable; 2) threatened (marginal or immediate); and 3) irreversible (Hardman et al. 2014), the Rutherford's guidelines classify CLI at 5 major levels: 1) asymptomatic, 2) mild caludication, 3) moderate claudication, 4) severe claudication, 5) ischemic rest pain, and 6) minor or major loss of tissue. The incidence of microbial infections in the ischemic wound may cause deterioration of functional muscle tissue. Moreover, amputation of the deceased region is inevitable in extreme cases of ALI.

Management of PAD mainly consists of risk factor modification, pharmacological interventions, and surgical revascularization. Of the 3 management options, revascularization involves surgical intervention, which can be achieved by either open surgery or endovascular means (Ouriel 2001). However, data obtained from both treatment options have not been encouraging. A multicenter, randomized controlled trial was conducted to treat PAD through open and endovascular surgery. This trial known as the "Bypass vs Angioplasty in 
Severe Ischemia of the Leg” (BASIL) trial, highlighted key factors involved in limb ischemia disease. Due to the terminal stage of the disease, $50 \%$ of enrolled patients suffering from CLI were found to be ineligible for revascularization intervention. Additionally, in patients who underwent the revascularization procedure, the prognosis remained poor (Adam et al. 2005). Due to the above-mentioned complications involved in the clinical management of PAD, the fundamental cause of the disease has been further explored by clinicians and basic scientists. Novel treatment strategies using growth factors, cells, and nanocarriers for the treatment of PAD have gradually evolved and are the focus of the current review. Taken together, this review condenses, the latest improvements in CLI treatment strategies offered through basic science and at the clinical level.

\section{Molecular basis of atherosclerosis}

Among the major vascular diseases, CLI is an end-stage PAD that, when compared to coronary occlusive disorders, is increasingly becoming life threatening (Teraa et al. 2016). Within 6 months from diagnosis, the estimated mortality due to CLI is $20 \%$, and it exceeds 50\% over the first 5 years (Teraa et al. 2016). One major complication during CLI is the formation of atherosclerotic plaques in the arterial wall. Development of a matured plaque undergoes a step-by-step growth process in the blood vessel. Arterial vessels are made up of 3 layers: the tunica adventitia (outer layer), the tunica media (middle layer), and the tunica intima (inner layer). The inner intimal layer, consisting primarily of endothelial cells and proteoglycans, adjusts to external stress (mechanical or chemical) by undergoing an adaptive remodeling process called intimal thickening. During diffuse or eccentrical intimal thickening, abnormal secretion of proteoglycans in the vascular bed is observed. Inflammatory macrophages and dendritic cells entrapped within the proteoglycan matrix will convert into foam cells (Bentzon et 
al. 2014). After death, these foam cells may act as a source of extracellular lipids that are deposited in the proteoglycan matrix. Prolonged accumulation of lipid matrix in combination with plasma lipids, such as low-density lipoprotein (LDL), eventually form the core of the atherosclerotic lesion (Bentzon et al. 2014). Progression of the lipid core occurs due to the necrosis of foam cells derived from vascular smooth muscle cells and results in calcification of the lesion. The formation of a fibrous cap around the lesion stabilizes the lesion in the artery which blocks the flow of blood and causes atherosclerosis (Bentzon et al. 2014).

\section{Signaling messengers and neovascularization}

The development of blood vessels involves 2 complex regulatory processes, namely arteriogenesis and angiogenesis. The formation of additional blood vessels from an established vascular network is known as angiogenesis. These newly formed vessels lack smooth muscle cells and basal substrata. In addition, arteriogenesis denotes the functional dilation of an existing artery and its subsequent growth into collateral vessels to form a natural vascular bypass(Heil et al. 2006). To distinguish angiogenesis from neovascularization, the molecular signaling mechanisms involved in both are discussed below.

\section{Angiogenesis}

Hypoxia, a major in vivo pathological stimulus is considered to be the most potent inducer of angiogenesis (Semenza 2007). The adaptive vascular responses that execute in hypoxic conditions are primarily mediated through a heterodimeric trans-acting factor, hypoxia inducible factor-1 (HIF-1). The transcription factor HIF-1 consists of 2 domains: a continually expressed HIF-1 $\alpha$ domain and a constitutively expressed $\beta$ domain (Wang and Semenza 1995). Synthesis of the HIF-1 $\alpha$ subunit is controlled by oxygen tension that is present in cells and their 
surrounding tissue (Wang et al. 1995). Under physiological conditions and normal oxygen levels, HIF-1 $\alpha$ is constitutively expressed, and is subsequently degraded by von Hippel-Lindau tumor suppressor protein (VHL) (Salceda and Caro 1997). The binding of VHL to HIF-1 $\alpha$ is mediated by hydroxylation of the amino acid proline at positions 402 and 564 by prolyl hydroxylase domain (PHD) enzymes (Selvaraju et al. 2014; Yu et al. 2001). However, during pathological hypoxia, the binding of VHL to HIF-1 $\alpha$ is inhibited, which leads to accumulation of HIF-1 $\alpha$ in hypoxia-prone ischemic tissues. Accumulated HIF-1 $\alpha$ triggers the activation of vascular endothelial growth factor (VEGF), fibroblast growth factor (FGF), platelet-derived growth factor subunit B (PDGFB), and angiopoietin (ANGPT) 1 and 2, which are involved in the formation of new blood vessels (Kelly et al. 2003). The PHD enzymes play a critical role in maintaining cellular HIF-1 $\alpha$ levels. In a previous study, we showed that homozygous disruption of the gene encoding PHD-1 (PHD-1 ${ }^{-/}$) increased the level of HIF-1 $\alpha$ in cardiac tissue and effectively protected the myocardium from ischemia-reperfusion injury (Adluri et al. 2011a). Furthermore, we showed that increased HIF-1 $\alpha$ levels activated the anti-apoptotic machinery through Bcl-2, $\beta$ catenin, endothelial nitric oxide synthase (eNOS), and p65 (nuclear factor $[\mathrm{NF}]-\kappa \mathrm{B}$ ), resulting in a decrease in cardiomyocyte apoptosis. In a separate study, we showed that femoral artery ligation in the hind limbs of PHD- $1^{-/}$and PHD- $3^{-/-}$mice resulted in improved motor function and vascular density compared with wild-type (WT) mice (Rishi et al. 2015). Moreover, PHD-1 $1^{-/-}$and PHD- $3^{-/-}$knockout mice showed increased VEGF, Bcl-2, and HIF-1 $\alpha$ expression compared with WT mice. Overall, our studies indicated that deleting PHD-1 and -3 may be a promising therapeutic approach for the treatment of PAD.

\section{Arteriogenesis}


In cells and tissues, the process of arteriogenesis is not triggered by hypoxic stimuli (Heil et al. 2006). After femoral artery ligation in a rabbit model, neither an increase in HIF-1 $\alpha$ synthesis nor upregulation of VEGF was observed (Deindl et al. 2001). If hypoxia does not initiate the process of arteriogenesis during pathological conditions, there must be an alternative cause for this process to occur. The occlusion of a functional artery at one end leads to a backward flow of blood and increased pressure. Backflow of blood in the artery causes shear stress in the endothelial lining of the blood vessel, and rarely leads to blood vessel expansion. Alternatively, increased blood flow and shear stress can be dissipated by flowing through preexisting collateral vessels. During pathological blood vessel obstruction, this phenomenon might be considered as the initiating event for the formation of arteriogenesis. Indeed, shear stress has been shown to stimulate the expression of endothelial cell adhesion molecules and chemokines, such as monocyte chemoattractant protein-1 (MCP-1) (Wung et al. 1996). In several reports, it was demonstrated that circulating monocytes in the blood adhere to collateral blood vessels, and secrete growth factors, such as basic FGF (bFGF) and tumor necrosis factor $\alpha$ (TNF $\alpha$ ), which may contribute to the process of arteriogenesis (Arras et al. 1998).

\section{Vasculogenesis}

In addition to arteriogenesis and angiogenesis, vasculogenesis is a third process involved in vessel formation and remodeling. Vasculogenesis originally referred to the embryological process of new blood vessel formation, in which bone marrow progenitor cells differentiate into endothelial cells for de novo vascular network formation (Carmeliet 2004). Studies by Tepper et al. showed that angiogenic factors were secreted in response to local tissue hypoxia, which attracted bone marrow (BM)-derived endothelial progenitor cells (EPCs) to the site of ischemic injury (Tepper et al. 2005). Endothelial progenitor cells migrated to the 
surrounding interstitial tissue, and proliferated rapidly to form cell clusters. Endothelial progenitor cell clusters reorganized to form cord-like vascular structures that effectively bridged with the existing blood vessel network to form stable and functional microvessels within the ischemic tissue.

\section{Experimental therapeutic strategies for treating PAD}

Secondary to the inherent limitations of existing treatment strategies, such as angioplasty, peripheral artery bypass graft, and stents, alternative treatment strategies have been considered for revascularization of the ischemic limb. Among the various molecules evaluated for angiogenic properties, growth factors are molecules of interest that have shown promising results, both in vitro and in vivo. In the 1970's, Judah Folkman was the first to introduce the theory of angiogenesis in tumor cells (Folkman 1974). Furthermore, his pioneering work showed that endothelial growth factors can be isolated from chondrosarcoma cells, which have a high affinity for the extracellular matrix molecule heparan sulfate (Shing et al. 1984). Following Folkman's findings, numerous studies were performed to establish the role of growth factors in amplifying adaptive neovascularization and perfusion in ischemic tissues. This process was later introduced as "therapeutic angiogenesis" (Isner et al. 1995).

Among the wide range of growth factors tested for angiogenesis, bFGF has shown an increase in collateral vessel growth in a rabbit hind limb ischemia (HLI) model (Baffour et al. 1992). Following this study, growth factors, including VEGF, insulin-like growth factor (IGF), granulocyte colony stimulating factor (G-CSF), hepatocyte growth factor (HGF), angiopoietin (ANGPT), PDGF, placental growth factors (PIGF), stromal-derived factor-1 (SDF-1), and transcription factors, such as HIF-1 $\alpha$, were used in both animal and human studies (Kalka and 
Baumgartner 2008; Losordo and Dimmeler 2004). The list above not only includes growth factors and transcription factors but also includes antioxidant proteins such as thioredoxin, and glutaredoxin, which are emerging as potential therapeutic candidates in the realm of angiogenesis (Dunn et al. 2010). The growth factors and redox proteins involved in angiogenesis and arteriogenesis are discussed below and shown in Figure 1.

\section{Fibroblast Growth Factor (FGF)}

The FGF superfamily includes 19 to 23 members (Nishimura et al. 1999) that all contain a specific binding domain for heparin and heparan sulfate. These domains are considered essential for executing FGF functional activities, such as binding to the extracellular matrix (Spivak-Kroizman et al. 1994). Among all members, FGF-1 and FGF-2 are the best-described isoforms in terms of their potent angiogenic function. Fibroblast growth factor 1 is an acidic 155 amino acid protein that lacks a signal peptide, which is required for channeling through the canonical secretory pathway (Powers et al. 2000). Studies have shown that fibroblast growth factor-1 possesses a nuclear localization motif, which plays a critical role in mitogenesis, and, when absent, leads to FGF-1 dysfunction (Imamura et al. 1990). By contrast, FGF-2 (bFGF) is a basic 18-KDa protein that shows a 55\% sequence identity to FGF-1 (Powers et al. 2000). Transcription of the FGF-2 gene can give rise to 4 different polypeptides (Florkiewicz and Sommer 1989). Like FGF-1, the FGF-2 protein lacks a signal sequence for secretion, and although a nuclear localization sequence is identified, the role of this sequence in FGF-2 activity remains unknown.

At present, 4 FGF receptor tyrosine kinases (RTKs) are known, including FGFR1, FGFR2, FGFR3, and FGFR4 (Partanen et al. 1992). It has been shown that FGFR1 is primarily 
expressed in the mesenchymal tissue, in contrast to FGFR2, which is mainly found in the epithelium (Florkiewicz and Sommer 1989). Heparin or heparan sulfate proteoglycans are essential for the activation of FGFR (Loo et al. 2001). Heparin is thought to interact with one of the immunoglobulin-like loops in the extracellular domain of the FGF receptor, thereby forming a ternary complex consisting of FGF (ligand), heparin/heparan sulfate proteoglycan, and the FGF receptor (Kan et al. 1993). FGF is a molecule with many functions. FGF1 and FGF-2 act as fibroblast and endothelial growth factors, respectively, and play vital roles in angiogenesis. In addition, FGF is required for 3 phases of wound healing, namely inflammation, repair, and regeneration. In the embryonic phase of development, FGF induces cell division and takes part in organogenesis involving the nervous system, lungs, and limbs (Chai et al. 1998).

\section{Vascular Endothelial Growth Factor (VEGF):}

The VEGF is an angiogenic growth factor that includes 5 different isoforms, VEGF-A, B, C, D, and PLGF (Ferrara et al. 2003). VEGF-A is the prototype of this family and a key regulator of vascular growth. The 5 well-established isoforms, VEGF 121, 145, 165, 189, and 206 are generated from alternative exon splicing of the VEGF gene (Neufeld et al. 1999). The VEGF isoforms are distinguished from each other by their ability to bind heparin and heparan sulfate. These VEGF variants contain amino acids encoded by exon 6 and/or 7 of the VEGF gene, thereby rendering them a higher affinity for heparin and heparan sulfate, and a high affinity for binding to the extracellular matrix (Park et al. 1993).

The second group of VEGF consists of secretory forms, including VEGF 121, 145, and 165. VEGF 121 is a secreted form of VEGF that does not have heparin or heparan sulfate binding ability (Gitay-Goren et al. 1996). Vascular endothelial growth factors 145 and 
165 can be present as either secreted or attached forms; only the secreted isoforms have extracellular matrix binding capacity (Poltorak et al. 1997). VEGF can bind to any of the RTKs, VEGFR-1 (Flt-1), and VEGFR-2 (KDR/Flk-1). A third group of receptors, VEGFR-3 (Flt-4), are only expressed in lymphatic vessels and are binding sites for VEGF-C and VEGF-D (Karkkainen et al. 2002). VEGF receptors consist of 2 functional domains: an extracellular domain with 7 immunoglobulin loops, and an intracellular domain with a split tyrosine kinase. Both VEGFR-1 and VEGFR-2 are predominantly expressed in endothelial cells. Levels of VEGF R-1 and VEGFR-2 were found to be up-regulated in hypoxic conditions (Waltenberger et al. 1996). Various studies have shown that, in early stages of development, inactivation of the allele related to the VEGF gene resulted in mortality of the embryo (Ferrara et al. 1996). VEGF, supports skeletal growth, endochondral bone formation (Gerber et al. 1999), and ovarian angiogenesis (Ferrara et al. 1998). In addition to physiological angiogenesis, VEGF also plays a major role in pathological angiogenesis after focal cerebral ischemia, especially in solid tumors (Kim et al. 1993), hematological malignancies (Gerber and Ferrara 2003), and brain edema (van Bruggen et al. 1999).

\section{Neuropilin (NRP1 and NRP2)}

Soker et al. identified the distinct cell-surface binding VEGF receptor, neuropilin (NRP) (Soker et al. 1996). NRP-1 differs from the existing VEGF receptors as it was primarily expressed in tumors and on endothelial cells. It was also found that VEGF 121 did not bind to the NRP-1 receptor. The main role of NRP-1 is to present VEGF 165 to VEGFR-2 and enhance VEGFR-2-mediated signal transduction (Soker et al. 1998). Neuropilin 1 is considered a vital receptor during embryonic development of the vascular system. Genetic knockdown of NRP receptors in mice $\left(\mathrm{NRP}^{-/-}\right.$mice) is lethal as $\mathrm{NRP}^{-/-}$mice undergo mortality during the embryonic 
stages of development (Kawasaki et al. 1999). Apart from the vascular system, NRP receptors are involved in coordination of the nervous system, where they mainly act as membrane receptors for class 3 semaphorins ( $\mathrm{Gu}$ et al. 2003). Recent studies in mice have shown that specific knockout of NRP-1 in cardiac myocytes and smooth muscle cells of vascular origin results in cardiomyopathy, impaired physical activity, decreased survival rates, ischemiainduced heart failure, and disordered global metabolic profiling (Yoshihara et al. 2014). No preclinical evaluation studies have been performed for NRP in the ischemic limb.

\section{Thioredoxin system}

The thioredoxin (Trx) system is a vital antioxidant system in mammalian cells, including the human body (Nordberg and Arner 2001). Three different isoforms of Trx have been identified (Arner and Holmgren 2000), including thioredoxin-1 (Trx-1), which consists of 105 amino acids and has a molecular weight of $12 \mathrm{kDa}$. Human Trx-1 contains 3 critical cysteine residues that provide unique biological properties to Trx-1 (Yoshihara et al. 2014). Thioredoxin 1 exists both in the cytoplasm and the nucleus, and controls the redox environment of the cell by interacting with oxidized proteins. Trx-1 is also involved in regulating the function of transcription factors, and thereby controls gene expression (Hirota et al. 1999). In the extracellular environment, Trx-1 acts as a chemoattractant molecule and signals inflammatory cells, such as T-cells, monocytes, and neutrophils (Bertini et al. 1999). Mitochondrial thioredoxin (Trx-2), a second Trx isoform, plays a key role in cell viability by neutralizing reactive oxygen species and apoptosis signaling pathways in mitochondria (Tanaka et al. 2002). Absence of Trx-2 leads to exencephaly, an open anterior neural tube, early embryonic lethality, and apoptosis (Nonn et al. 2003). Another Trx isoform is found only in male gamete 
spermatozoa and is commonly referred to as SpTrx. Its oxidizing activity is critical for the development of spermatids and spermatozoa (Miranda-Vizuete et al. 2001).

The Trx system consists of Trx, Trx reductase, and NADPH. Reduced Trx forms cause reduction of oxidized substrate proteins and are converted into oxidized Trx. In the presence of cofactor NADPH, oxidized Trx is reversibly converted into reduced Trx by the action of the enzyme Trx reductase (Dunn et al. 2010; Nordberg and Arner 2001). Trxinteracting protein (TXNIP) is a newly identified protein that is considered an endogenous inhibitor of Trx. Trx-interacting protein effectively forms a disulfide bond with reduced Trx, and inhibits it from undergoing reversible oxidation (Saxena et al. 2010). Recently, Chen et al. identified TXNIP as a pro-apoptotic factor in $\beta$ cells of the pancreas during hyperglycemic conditions. The inhibition of TXNIP offers a protective effect in $\beta$ cells and may protect against diabetes mellitus (Chen et al. 2008). Thioredoxin is involved in numerous signaling pathways that are related to angiogenesis; for example, Trx can modulate the expression of key transcription factor protein NF- $\kappa$ B (Das 2001). In addition, Trx-1 can enhance the activity of HIF- $1 \alpha$ by regulating the redox status of the cell, followed by increased expression of VEGF and NOS (Welsh et al. 2003). The role of Trx-1 during diabetes mellitus is well studied, and it was shown that Trx-1 activity was highly reduced with increased expression of TXNIP protein under hyperglycemic conditions ( $\mathrm{Li}$ et al. 2009). Furthermore, in infarcted myocardium of diabetic rats it was demonstrated that adenoviral-mediated overexpression of Trx-1 enhanced angiogenesis and improved cardiac function (Adluri et al. 2011b; Samuel et al. 2010) (Figure 2). Recently, Dunn et al. studied the hyperglycemic modulation of TXNIP and Trx proteins in diabetic mice subjected to HLI. Their results show that knockout of TXNIP reduced the deleterious effect of hyperglycemia and improved angiogenesis (Dunn et al. 2009; Dunn et al. 2010). Furthermore, it 
was revealed that Trx1 overexpressed transgenic $\left(\operatorname{Trx}-1^{\mathrm{Tg}+}\right)$ mice show improved revascularization and decreased fibrosis following femoral artery ligation compared to WT mice (Thirunavukkarasu et al. 2014). In a recent study, we found that adenoviral-mediated overexpression of Trx-1 as well as transgenic Trx-1 overexpression enhanced blood perfusion and angiogenic protein expression in a murine HLI model. Taken together, we demonstrated that the Trx system is a promising system with potential to rescue the hind limb from ischemic peripheral vascular disease.

\section{Hepatocyte Growth Factor (HGF)}

In 1984 , Nakamura et al. identified a $150-\mathrm{kD}$ anionic protein in the serum of rats that underwent partial hepatectomy (Nakamura et al. 1984). Addition of this protein to hepatocytes culture induced hyperproliferation. Therefore, this protein was named HGF or hepatotropin (HGF). HGF is a heterodimer consisting of 2 subunits, a 69-kDa alpha subunit and a 34-kDa beta subunit (Matsumoto and Nakamura 1992). HGF acts as a ligand for a receptor encoded by the MET proto-oncogene (p190 $\left.{ }^{\mathrm{MET}}\right)$, a transmembrane tyrosine kinase (Bottaro et al. 1991). In 1992, Bussolino et al. showed that HGF is a potent angiogenic factor that stimulates endothelial cell motility and growth (Bussolino et al. 1992). Upon binding to the p190 receptor expressed on endothelial cells, HGF activates RTKs. Subsequent phosphorylation of the $\beta$-subunit of RTKs leads to intracellular signals and ligand-specific biological responses (Bussolino et al. 1992). HGF possesses multiple roles, such as stimulation of chemotaxis and chemokinesis of endothelial cells and expression of the enzyme urokinase for matrix degradation, as well as endothelial cell invasion and angiogenesis (Montesano et al. 1991; Pepper et al. 1992; Silvagno et al. 1995). HGF has also been shown to promote the proliferation and differentiation of multipotent and erythroid progenitor cells (Galimi et al. 1994). 


\section{Prolyl-4-Hydroxylase Domain and Hypoxia Inducible Factor Group of Proteins}

Prolyl-4-hydroxylase domain proteins play a crucial role in the process of angiogenesis by sensing cellular oxygen levels. In mammalian cells, 3 different variants of PHD have been identified, the differences being in the organ-specific isoenzyme expression of PHD-1 (EglN2), PHD-2 (EglN1), and PHD-3 (EglN3) (Selvaraju et al. 2014). The cellular actions of PHDs are regulated by HIF, the HIF-1 $\alpha$ subunit being the most important downstream regulator of angiogenesis (Adluri et al. 2011a). When stabilized, the PHD $\alpha$ subunit translocates to the nucleus where it dimerizes with the $\beta$-subunit. The constituted dimer acts as an active transcription factor, and binds to the hypoxia-response element (HRE) sequence that is present upstream of angiogenic genes. Subsequently, transcription and translation of angiogenic proteins, such as VEGF, eNOS, and PDGF stimulate angiogenesis (Semenza 2003). In the complex cellular environment, PHD proteins affect a number of pro-angiogenic molecules. As discussed above, we found that mice deficient in PHD-1 and PHD-3 show significantly improved recovery of motor function and increased vascular density after femoral artery ligation when compared with WT mice (Rishi et al. 2015). Thus, knockdown of PHD-1 and PHD-3 may offer potential therapeutic benefits for patients in the terminal stage of PAD [Figure 3].

\section{Preclinical trials with growth factor therapy to treat PAD}

Numerous studies have focused on the therapeutic potential of growth factors in various pathological diseases. In the 1990s, Baffour et al. evaluated the role of bFGF in collateral blood vessel growth in a rabbit HLI model. Their results showed that, after 14 days of bFGF treatment, collateral blood vessels and angiogenesis augmented the therapeutic outcome in bFGF-treated rabbits compared with control rabbits (Baffour et al. 1992). Additionally, Pu et al. 
investigated the role of acidic FGF (aFGF) in a rabbit model of HLI (Pu et al. 1993). After 10 days of ligation of the iliac artery and complete excision of femoral arteries, intramuscular administration of aFGF was performed. The results of the angiographic and hemodynamic studies showed enhanced neovascularization and perfusion in a FGF-treated ischemic limb compared with the controls. Similar experimental studies have been performed to verify the importance of VEGF in PAD animal models. Takeshita et al. showed that, in a rabbit model of HLI, intramuscular administration of VEGF resulted in a dose-dependent significant increase of collateral blood vessel formation and blood perfusion (Takeshita et al. 1994). Various preclinical studies have been subsequently performed to evaluate the in vivo efficacies of FGF, VEGF, and other growth factors in different models of disease (Lebherz et al. 2003; Li et al. 2007; Taniyama et al. 2001).

\section{Clinical trials (phase I, II, and III) with growth factor therapy to treat PAD:}

\section{Fibroblast Growth Factor (phase 1 trial)}

A phase I multicenter clinical trial was conducted among 51 patients with unreconstructible end-stage PAD to evaluate the safety and tolerance of naked plasmid DNA encoding FGF type 1 (NV1FGF). Patients received increasing single and repeated doses of NV1FGF into their ischemic thigh and calf muscles and recovery was observed for 6 months. The data indicated that NV1FGF was well tolerated with no serious side effects related to treatment. Although 2 deaths were reported among the patients who received NV1FGF treatment, neither was considered related to the experimental study. After 8 and 12 weeks of NV1FGF treatment, a significant increase in the ABI was observed without any changes in the toe brachial index (TBI). Moreover, increases in transcutaneous oxygen pressure were observed 
after 8 and 12 weeks of NV1FGF treatment. Similarly, all patients reported a decrease in mean pain level at 8 and 24 weeks after treatment. Ulcer healing was evaluated in 9 patients who showed decreases in aggregated ulcer size over time (Comerota et al. 2002; Henry et al. 2002).

To determine plasmid distribution and NV1FGF transgene expression, a separate pharmacokinetic trial using NV1FGF was performed. Included in this trial were 6 patients who suffered from CLI and were scheduled for amputation. Variable doses of NV1FGF $(0.5,2$, or 4 mg) were administered intramuscularly 3 to 5 days before amputation. Muscle samples harvested from the injected and non-injected amputation sites indicated plasmid DNA delivery and corresponding transgenic protein expression. The results confirmed transgene expression at all doses used with the expression of FGF receptors at the injection site. The levels of NV1FGF in blood plasma were found to gradually decrease after injection. Furthermore, the expression of FGF-1 was limited to the injection site, supporting the concept of multiple site injections for therapeutic usage (Baumgartner et al. 2009). Similar results were observed in several other phase I clinical trials using FGF (Hashimoto et al. 2009).

\section{Vascular Endothelial Growth factor (phase 1 trial)}

In 1996, Isner et al. reported the first clinical trial using VEGF gene therapy to treat CLI in humans (Isner et al. 1996). In this trial, a 71-year-old female patient received a human plasmid vector carrying the VEGF gene (phVEGF165) that was administered intra-arterially. Human plasmid phVEGF 165, at a dose of $2000 \mu \mathrm{g}$, was loaded in a polymeric hydrogel for coating an angioplasty balloon. Four weeks after VEGF therapy, the angiography results showed an increase in collateral vessels in the knee, mid-tibia, and ankle. Doppler analysis showed an increase of $82 \%$ in resting and $72 \%$ in maximum blood flow (Isner et al. 1996). This same group 
conducted a phase 1 clinical trial using naked plasmid DNA encoding VEGF 165. The goals of this trial were to evaluate the safety and feasibility of intramuscular gene transfer and analyze the potential therapeutic benefits in patients with peripheral vascular disease. Intramuscular administration of phVEGF $165(4000 \mu \mathrm{g})$ above and below the knee joint resulted in a temporary increase in the VEGF level in the systemic circulation of 7 patients after 1 to 3 weeks of treatment. Similarly, ABI and TBI were increased compared with baseline levels. The data not only showed an increase in collateral blood vessel growth by contrast angiography, but also qualitative evidence of distal flow through magnetic resonance angiography. Therapeutic proof of treatment was demonstrated by a concomitant decrease in rest pain and ulcer size with salvage of the limb in 3 patients who were initially recommended for BKA (Baumgartner et al. 1998; Baumgartner et al. 2000). There were a number of limited complications, the most important being increased vascular permeability secondary to VEGF treatment, with trivial adverse events as documented by later studies. In 2001, the same group published results from a phase 1 , doseescalating trial showing that intramuscular phVEGF 165 gene transfer improved chronic ischemic neuropathy associated with CLI (Simovic et al. 2001).

Recently, Kim et al (Kim et al. 2004) studied the safety of naked plasmid DNA encoding VEGF gene therapy. This was an open-label, dose-escalating, single-center trial that included 9 male patients. Three escalating doses of 2, 4, and $8 \mathrm{mg}$ plasmid DNA containing human VEGF 165 (pCK-VEGF) were used. During 9 months of follow-up, no significant side effects related to gene transfer were detected. In addition, plasma levels of VEGF were not elevated, and rest pain, ischemic ulcers, and ABI were improved. Subsequent angiography analysis revealed the growth of collaterals throughout the injection site. No correlation was 
observed between the dose given and effect seen. Similar phase 1 studies using VEGF have been performed by different groups with encouraging results (Mohler et al. 2003; Shyu et al. 2003).

\section{HGF and HIF-1 $\alpha$ (phase I trial)}

In previous studies, the therapeutic benefits of naked HGF plasmid DNA in ischemic hind limb disorders were investigated. To date, 3 trials have documented growth factors other than VEGF and FGF. In 2004, Morishita et al. (Morishita et al. 2004) investigated the safety of HGF in the treatment of PAD in an open-label, phase I/early phase IIa clinical trial. During the 12-week follow-up period, complications were reported in 6 patients with CLI that were related to gene transfer. No changes in serum HGF levels were detected, and unlike clinical trials involving VEGF, no increased peripheral edema was reported. Furthermore, patients reported a decrease in pain scale with improvements in ABI and ulcer size. Similarly, a study in CLI patients by Rajagopalan et al. in 2006 (the results of a phase I, dose-escalating, multicenter clinical trial) showed the safety and clinical response of transcription factor HIF-1 $\alpha$ (Ad2/HIF$1 \alpha$ ) in these patients (Rajagopalan et al. 2007). In 2011, Henry et al. reported the results of a phase I study, which involved the intramuscular injection of a non-viral plasmid DNA expressing 2 isoforms of human HGF (VM202). The injection was shown to be safe and associated with a favorable clinical outcome (Henry et al. 2011).

FGF (phase II trial) - Therapeutic Angiogenesis with FGF-2 for Intermittent Claudication (TRAFFIC) study:

In 2002, a phase II, randomized, double-blind, placebo-controlled study (the TRAFFIC study) was performed using recombinant fibroblast growth factor-2 (rFGF-2) therapy for intermittent claudication. This trial investigated whether single or double intra-arterial doses 
of rFGF-2 are essential for improved exercise capacity in 174 patients suffering from moderateto-severe levels of intermittent claudication. The results indicated that a single intra-arterial rFGF-2 injection at a dose of $30 \mu \mathrm{g} / \mathrm{kg}$ significantly increases peak walking time (PWT) at 90 days with no further improvement in response with a repeated dose at day 30. A secondary objective of increased ABI at days 90 and 180 was not achieved (Lederman et al. 2002).

\section{FGF (phase II trial) - Therapeutic Angiogenesis Leg Ischemia Study for Management of Arteriopathy and Non-healing ulcer (TALISMAN 201) study:}

In a double-blind, randomized, placebo-controlled multinational study (TALISMAN 201), the efficacy and safety of NV1FGF were evaluated. The results of this study were published in 2008 (Nikol et al. 2008a, b). A total of 125 patients who presented with irreversible ischemia with non-healing ulcers were evaluated. Patients were randomized into groups and received 8 intramuscular injections of either placebo or $16 \mathrm{mg}$ of NVIFGF at days 1 , 15, 30, and 45. Three notable results were observed in this study. First, the use of NV1FGF significantly decreased the risk level of amputations. Second, a trend was observed for reduced mortality due to NV1FGF treatment. Third, the trial failed to show any significant improvement in healing of ulcers, which could have been due to non-standardized wound care and variation in the severity of skin ulcers among patients (Nikol et al. 2008b).

\section{VEGF (phase II trial)}

In 2002, Makinen et al. published the results of a randomized, placebo-controlled, double-blind, phase II study with VEGF gene therapy in patients with chronic lower limb ischemia (Makinen et al. 2002). Gene therapy was carried out during angioplasty. AdVEGF was administered to 18 patients, plasmid VEGF was given to 17 patients, and 19 control subjects 
received ringer's lactate. In patients who received VEGF treatment, the levels of anti-adenoviral antibodies increased. In addition, no major effects were detected that were related to gene transfer. After a 90-day period, digital subtraction angiography (DSA) demonstrated increased vasculature in VEGF-treated patients. This increase in vasculature was located in the region of clinically severe ischemia in the AdVEGF group, thus reaching the primary endpoints (DSA analysis of vascularity). The secondary endpoint (restenosis) showed increases in ABI and Rutherford class at 3 months however these effects were seen in all groups. In this trial, angioplasty was performed at the same time as the intra-arterial gene transfer, which may have acted as a confounding variable (Kalka and Baumgartner 2008; Makinen et al. 2002).

The Regional Angiogenesis with VEGF (RAVE) study was a randomized, double-blind, placebo-controlled, multicenter phase II study published by Rajagopalan et al. in 2003 (Rajagopalan et al. 2003b). This study focused on the efficacy and safety of replicationdeficient adenovirus encoding VEGF 121 (AdVEGF 121) given intramuscularly in a cohort of 105 subjects with unilateral PAD. Patients were stratified based on their diabetic status and were randomized into groups to receive either a low dose $\left(4 \times 10^{9}\right.$ AdVEGF), a high dose $\left(4 \times 10^{10}\right.$ AdVEGF), or placebo control in the index limb. Gene therapy was confined to a single session. Unfortunately, the study did not achieve its primary objective, i.e. a change in PWT at 12 weeks, or secondary objectives, i.e. a change in PWT at 26 weeks, as well as changes in ABI, claudication onset time, and quality of life (Rajagopalan et al. 2003a). Investigators of the RAVE study presented 2 possible explanations for the negative results of their study. First, they deliberately selected patients with unilateral PAD symptoms, which could include those with unilateral disease. This was intended because the drug was being delivered unilaterally, and differed from previous trials in which patients with the bilateral disease were included. Secondly, 
the efficacy of AdVEGF ${ }^{121}$ administered in a single session was questionable, as studies have shown that premature cessation of VEGF stimulus for 2 weeks leads to regression of acquired blood vessels. In addition, at least 4 weeks of continued stimulation are required for blood vessels to become refractory to VEGF stimulation. Negative results obtained from the RAVE study were followed by 2 additional trials. One trial focused on the role of VLTS-589 (plasmid encoding the angiomatrix protein Del-1) in the treatment of patients with intermittent claudication (Rajagopalan et al. 2004) the other study focused on the role of phVEGF165 in diabetic patients with CLI (Kusumanto et al. 2006). Neither of the trials showed promising results.

\section{HGF (phase II trial)}

In 2008, a double-blind, randomized, placebo-controlled phase II clinical trial was completed in which researchers investigated the safety and efficacy of plasmid encoding HGF to improve limb perfusion in patients suffering from CLI (HGF-STAT trial) (Powell et al. 2008). Three dose regimens were tested: 1) $0.4 \mathrm{mg}$ at 0,14 , and 28 days (low dose); 2) $4.0 \mathrm{mg}$ at 0 and 28 days (middle dose); or 3) $4 \mathrm{mg}$ at 0,14 , and 28 days (high dose). Serious side effects observed were all related to the primary disease and not to the treatment. At the end of 6 months of follow up, the transcutaneous partial pressure of oxygen $\left(\mathrm{TcPO}_{2}\right)$ was found to be significantly higher in the high-dose group compared with the other groups. The trial failed to reach its secondary objectives, including improved ABI, TBI, pain relief, major amputation, or wound healing (Powell et al. 2004). The same group continued their study, and published the results of a randomized, placebo-controlled multicenter trial (HGF-0205 trial) in 2010. The HGF plasmid injection site was individualized for each patient using angiography, magnetic resonance angiography (MRA), or computed tomographic angiography (CTA) to define the vascular 
anatomy and ensure that the injection was given at the site of most severe disease. At the end of 6 months of follow up, the HGF-treated group showed significant increases in TBI and visual analog score (VAS) compared with the placebo group. At 12 months, no significant changes were found in complete ulcer healing, major amputation, or mortality (Powell et al. 2010). A study conducted by Shigematsu et al. showed similar results with the use of HGF in patients with CLI (Shigematsu et al. 2010).

\section{FGF (phase III trial)}

A phase III, randomized, double-blind, placebo-controlled, multinational clinical trial was conducted by Belch et al, to study the therapeutic effect of NV1FGF in patients who underwent amputation or died due to CLI. Patients were given 8 intramuscular injections of 0.5 mg NV1FGF or matching placebo control in the index limb on days 1, 15, 29, and 43. Neither the primary endpoint (time to major amputation of treated leg or death from any cause at 1 year), nor the main secondary endpoints (major amputation or death from any cause within 12 months, analyzed separately) were reached. These results contrasted with those of a phase II study on FGF (TALISMAN), which showed significant benefits in secondary endpoints (major amputation), and combined endpoints (major amputation or death, whichever came first). These differences are surprising given that the study design, treatment dosing, and inclusion and exclusion criteria were similar to both studies. More diabetic patients and those with end-stage renal disease were included in the TAMARIS study; however, elimination of these subgroups did not alter the results. (Belch et al. 2011).

\section{HGF (phase III trial)}


Following the promising results of phase II clinical trials reported by Powell et al., a phase III trial was initiated in 2014 to assess the efficacy of HGF in patients with CLI. This pivotal study is ongoing and will be analyzed at a later date to confirm the efficacy of HGF treatment.

\section{Cell therapy}

A discussion on therapeutic revascularization in CLI would not be complete without considering cell therapy. Cell-based therapy has been considered a potential therapeutic modality for revascularization since 2002, when the Therapeutic Angiogenesis using Cell Transplantation (TACT) trial became the first randomized controlled trial to evaluate the effects of stem cell therapy in PAD (Tateishi-Yuyama et al. 2002). To obtain a global understanding of cell therapy in the treatment of PAD, it is important to differentiate among the various types of stem/progenitor cells.

\section{Unfractionated bone marrow}

Unfractionated bone marrow cells (BMC), also referred to as bone marrowderived mononuclear cells (BM-MNC) to be differentiated from mononuclear cells of peripheral blood, were the first cells to be studied for their role in revascularization. Endothelial progenitor cells, which differentiate into vascular endothelial cells and thereby release angiogenic cytokines, originate from stem cells within the BM.

Pre-clinical: The question of whether BM transplantation could be used to produce functional endothelial cells was first addressed by Shintani et al. in 2001 by studying BM transplants in rabbits after surgically-induced HLI (Shintani et al. 2001). The research group concluded that at the pre-clinical level functional endothelial cells develop from BM-MNCs and 
autologous transplantation of BM-MNCs augments collateral vessel formation in response to ischemic insult.

Clinical: A year later, in 2002, Tateishi-Yuyama et al. (Tateishi-Yuyama et al. 2002) conducted the first randomized controlled trial (TACT trial) to evaluate the effect of stem cells in PAD. They demonstrated clinical improvements, such as statistically significant improvements in ABI, pain-free walking time, and rest pain, with BM-MNC treatment. Another important clinical trial to study BM-derived therapeutic revascularization was performed in 2011 with a randomized, placebo-controlled intra-arterial Progenitor Cell Transplantation of BMMNC for Induction of Neovascularization in Patients With Peripheral Arterial Occlusive Disease (PROVASA trial) (Walter et al. 2011). Following administration of intra-arterial BM-MNCs to patients suffering from CLI, significant decreases in ulcer size and pain score were observed compared with the placebo group. In 2015, the Rejuvenating Endothelial Progenitor Cells via Transcutaneous Intra-arterial Supplementation (JUVENTAS) trial, a randomized, double-blind, placebo-controlled study did not show promising results (Teraa et al. 2015). Compared with the placebo group, repetitive infusion of autologous BM-MNCs through the common femoral artery did not reduce amputation rates in CLI patients. A limitation of studies of BM-derived therapy lies in the invasive nature of the BM harvest; autologous peripheral blood mononuclear cells (PB-MNC) offer a less invasive option.

\section{Peripheral blood mononuclear cells}

In 1997, a group of scientists at Tufts University successfully isolated EPCs from peripheral blood (Asahara et al. 1997). Using magnetic beads, endothelial cell progenitors were 
successfully isolated from human peripheral blood. This discovery in the field of stem cell-based therapeutic angiogenesis would have tremendous clinical implications.

Pre-clinical: Given their exciting discovery, the same group initiated pre-clinical trials utilizing peripheral blood mononuclear stem cells and found that endothelial progenitor cells isolated from peripheral blood improved blood flow in HLI-induced animals (Asahara et al. 1999). This model was further investigated by Kalka et al. (Kalka et al. 2000) who intramyocardially injected peripheral blood derived mononuclear stem cells 1 day after HLI induction in mice (Kalka et al. 2000). Although the sample size was relatively small (including less than 20 animals), the study demonstrated in the treatment group a profound improvement of perfusion (analyzed by laser Doppler imaging) and neovascularization (analyzed by immunohistochemistry). Based on this and similar studies, clinical pilot studies were designed.

Clinical: In 2005, Huang et al. (Huang et al. 2005) conducted a landmark trial in the study of peripheral mononuclear cells in angiogenesis, and provided evidence of clinical improvement after autologous transplantation of PB-MNCs in CLI patients. In diabetic CLI patients, the randomized controlled trial showed improvements in perfusion, ABI, limb pain, and amputations over the course of 3 months after stem cell transplantation. In 2012, similar results were obtained by Ozturk et al. (Ozturk et al. 2012) in diabetic CLI patients who were treated with autologous peripheral blood mononuclear cell transplantation. Granulocyte colony stimulating factor was used to mobilize PB-MNCs from peripheral blood. Granulocyte-colony stimulating factor (G-CSF) was used to mobilize PB-MNCs from peripheral blood (Ozturk et al. 2012). Similarly, angiogenesis was investigated in G-CSF-mobilized CD $34^{+}$cells. (Kawamoto et al. 2009) and Kinoshita et al. (Kinoshita et al. 2012) the short- and long-term effects of intramuscular treatment of G-CSF in CLI patients (Kawamoto et al. 2009; Kinoshita et al. 2012). 
The phase I and II trials demonstrated favorable clinical outcomes supporting the benefit of GCSF-mobilized CD34 ${ }^{+}$cell transplantation in CLI patients. Phase III trials by the same group of researchers are currently in progress. Similarly, Losordo et al. (Losordo et al. 2012) showed that, in CLI patients who underwent G-CSF treatment, mobilization of CD34 ${ }^{+}$cells resulted in a decreased number of amputations. In conclusion, the use of G-CSF-mobilized PB-MNCs or CD34+ cells may be a promising approach to treat patients with CLI.

\section{Bone marrow-derived mesenchymal stem cells}

Unlike the BM-MNCs and PB-MNCs discussed earlier, BM-derived mesenchymal stem cells (BM-MSC) are pluripotent stromal cells with the ability to differentiate into various cell types. While BM-MNCs can only differentiate into EPCs, BM-MSCs can differentiate into osteoblasts, chondrocytes, myocytes, or adipocytes.

Pre-clinical: The role of BM-MSCs in therapeutic angiogenesis was evaluated in a rat model of HLI by Iwase et al. (Iwase et al. 2005). In this study, BM-MNC therapy, BMMSC therapy, and a control group were compared. BM-MSC therapy demonstrated improved perfusion (although not as much as BM-MNC therapy) and capillary density with decreased apoptosis.

Clinical: BM-MSC therapy was shown to be effective on a clinical level by Lu et al. (Lu et al. 2011) and Gupta et al. (Gupta et al. 2013) in double-blind, randomized, placebocontrolled phase I and II trials. Lu and colleagues compared BM-MNC therapy, BM-MSC therapy, and placebo therapy in diabetic CLI patients. The ABI and MRA showed clinical improvements induced by BM-MSC transplantation, which were more significant than those observed with transplantation using BM-MNCs. Gupta et al. (Gupta et al. 2013) verified the 
safety of BM-MSC administration and evidenced improvements in ABI with BM-MSC therapy compared with the placebo group. Pre-clinical and early clinical data have suggested that MSC therapy is a promising approach in the field of therapeutic angiogenesis. A recent clinical report by Liu et al (Liu et al. 2015) showed that infusion of BM-derived MNCs and MSCs for the treatment of CLI in a group of 275 patients significantly improved ABI and ulcer healing until 6 months after therapy. The improved healing response in patients could have been due attributed to a small population of EPCs present in the injected stem cell pool that facilitated the process of angiogenesis.

\section{Adipose-derived stem cells}

Adipose tissue (fat) contains, like BM and peripheral blood, pluripotent stem cells. The ability to harvest autologous stem cells for therapeutic purposes from fat tissue holds great potential as adipose tissue is readily available and very abundant.

Pre-clinical: A pre-clinical study by Miranville et al. (Miranville et al. 2004) demonstrated improvement of neovascularization secondary to adipose tissue-derived stem cell therapy. In a HLI mouse model, which simulated CLI, intravascular administration of human adipose tissue-derived stem cells augmented the capillary density and blood flow in the ischemic leg. Five years later, another pre-clinical trial demonstrated similar results. Kondo et al. (Kondo et al. 2009) showed that the injection of adipose-derived stem cells improved angiogenesis in the ischemic zone. In this study, the mouse HLI model showed improved perfusion and capillary density in the cell therapy group.

Clinical: One notable clinical trial was conducted in 2013 by Marino et al. (Marino et al. 2013). Twenty patients with CLI and secondary chronic lower extremity ulcers 
were evaluated over a period of 90 days. Patients treated with adipose-derived regenerative cell therapy showed reduced ulcer size and pain compared with the untreated group. In $60 \%$ of the adipose-derived regenerative cell therapy-treated patients in this trial, the ulcers healed completely. However, the small sample size and lack of a placebo control place limits on the interpretation of and confidence in these staggering results. Another important clinical trial was the 2014 phase I Adipose CELL Derived Regenerative Endothelial Angiogenic Medicine (ACellDREAM) trial, which demonstrated the safety and feasibility of autologous adiposederived stem cell transplantation in patients with nonrevascularizable CLI. The outcomes of this trial included improved wound healing with therapy (Bura et al. 2014). Although adipose is an accessible and available source of stem cells, its role in therapeutic angiogenesis requires additional clarification.

\section{Induced pluripotent stem cells}

Pluripotent stem cells can be induced into mesenchymal stem cells and endothelial cells and the nuclear re-programmed cells can be used as cell therapy. Skin cells have been identified as an excellent source of inducible pluripotent stem cells. Although skin fibroblasts remain the main cells of interest, new sources of inducible pluripotent stem cells are continuously being investigated. For example, dental pulp has been identified as a potential source of stem cells due to its revascularization potential (Yoo et al. 2013). Therefore, like adipose tissue, inducible pluripotent stem cells offer a promising, less invasive, alternative source of stem cells. Although this area needs further investigation on a clinical level, preclinical studies have demonstrated promising potential. 
Pre-clinical: Human skin fibroblasts can be induced to differentiate into mesenchymal stem cells and, ultimately, endothelial cells. In 2010, Lian et al.(Lian et al. 2010) successfully transformed human inducible pluripotent cells into mesenchymal stem cells, which were subsequently administered to mice with HLI. Both improved perfusion and blood vessel formation were found after treatment with induced pluripotent stem cells. Moreover, in pluripotent stem cell-treated limb ischemic mice, the degree of improved perfusion and blood vessel formation was greater when compared with BM-MSC-treated limb ischemic mice. In 2011, Rufaihah et al. (Rufaihah et al. 2011) conducted a pre-clinical study to demonstrate that induced pluripotent stem cells from a human source differentiated into vascular endothelial cells. When applied therapeutically, the differentiated endothelial cells improved blood perfusion in the ischemic zone of the hind limb.

Clinical: Clinical studies utilizing inducible pluripotent stem cells for therapeutic angiogenesis have yet to be published. However, pre-clinical trials have laid the groundwork for this work.

The 4 main sources of autologous stem cells that are studied for their role in therapeutic angiogenesis in the ischemic limb model are: 1) BM (unfractionated or not), 2) peripheral blood, 3) adipose tissue and 4) skin cells. Each of these subsets of stem cells has demonstrated strong evidence of therapeutic angiogenic properties at the pre-clinical level, thereby providing a solid basis for clinical research in the field.

Clinically, unfractionated BM, the first to be studied for its therapeutic angiogenic abilities, has been investigated in double-blind, placebo-controlled, randomized studies. Unfortunately, only 2 out of the 3 studies conducted demonstrated promising results. The most 
recent study the 2015 JUVENTAS trial, showed no improvement in ischemia when compared with the placebo control (Teraa et al. 2015). Regardless of these results, BM harvest is an invasive procedure, which is not only difficult to study but also difficult to use clinically. Peripheral blood provides an excellent source of EPCs that are similar to the cells that arise from the BM. Phase I and II clinical trials have shown promising therapeutic effects in patients with CLI, secondary to peripheral blood derived mononuclear stem cell therapy. Phase III trials are underway, and there are high hopes for additional positive effects. Adipose tissue, like peripheral blood, is both abundant and easily accessible and phase I clinical trials show promising results. However, few randomized control trials have been conducted in which adipose stem cell therapy is used to treat peripheral vascular disease. Although adipose tissue is an accessible and available source of stem cells, its role in therapeutic angiogenesis requires further investigation.

Bone marrow, peripheral blood, and adipose tissue are the primary sources of stem cells evaluated for their angiogenic potential. Other sources of stem cells, such as skin and dental pulp that give rise to inducible pluripotent stem cells have yet to be explored on a clinical level. The future of cell therapy research is bright and vast. Using cell-surface markers, specific cell lines can be identified and isolated. Although not specifically included in this review, such marker-selected cell lines may represent small subsets of cells that hold great potential. The full potential of stem cell-based therapy for peripheral vascular disease is yet to be uncovered; however, cell-based therapy remains at the forefront of therapeutic angiogenesis.

\section{Nanocarriers in HLI}

Recent advances in nanotechnology have revolutionized the field of therapeutic drug delivery through advanced nanocarrier systems. The use of nanocarriers allows the delivery 
of drugs to be controlled at multiple levels. Nanoformulations that are tested for HLI include proangiogenic molecules, encapsulated nanoparticles, proangiogenic gene/plasmid-loaded liposomal formulations, and proangiogenic peptide-mimicking nanofibers. The major advantage of nanocarriers is their capability to deliver drugs at a specific site of tissue requirement, thereby reducing drug toxicity to healthy cells. The following section briefly describes recently employed nanocarrier systems used for the treatment of HLI at the pre-clinical level. The carboxyl quantum dot nanoparticles surface conjugated with cationic polyethyleneimine (PEI) forms ionic complexation with the negatively charged VEGF 165 plasmid vector. The obtained VEGF-decorated polyplex nanocarriers effectively transfects human umbilical cord bloodderived EPCs in vitro and induces angiogenesis in vivo. The nanoformulation consisting of VEGF-transfected EPCs and quantum dots (QD) has shown increased in vivo imaging signals and stimulated blood perfusion in ischemic limbs by secreting angiogenic factors (Yang et al. 2012).

In a different study, human umbilical vein endothelial cells (HUVECs) and MSCs were organized into 3D cell spheroids using methylcellulose hydrogel. When cell-encapsulated hydrogels were injected into the critical limb ischemic zone of a mouse model, blood perfusion was improved, and blood vessel sprouting and expansion in all directions aided in vasculogenesis (Chen et al. 2013). In HLI studies, fluorescently-labeled gelatin nanoparticles were prepared and characterized as a diagnostic tool for fluorescent non-invasive imaging (Zhang et al. 2015). Poly(lactic-co-glycolic acid) nanoparticles capped with cationic PEI were used to load the angiogenic peptide apelin. The net positive charge of the nanoparticles forms an ionic complex with negatively-charged plasmid DNA encoding VEGF. The angiogenic nanoparticles efficiently transfected human mesenchymal stem cells. Moreover, when injected intramuscularly into the 
HLI area, the apelin-loaded nanoparticle formulation along with plasmid VEGF showed improved blood perfusion and blood vessel formation compared with the non-VEGF formulation (Park et al. 2016). When novel self-assembling nanofibrous peptide hydrogels (SLanc: K(SL)3(RG)(SL)3-K-G-KLTWQELYQLKYKGI) synthesized by Kumar et al. (Kumar et al. 2016), were injected into animals with HLI, high blood perfusion and skeletal muscle formation was observed. In addition, injection of human adipose stem cells cultured in 3D spheroids into the ischemic limb showed enhanced differentiation into endothelial and smooth muscle cells. Moreover, improved angiogenesis and skeletal muscle formation after 21 days post treatment were found (Park et al. 2014). The self-assembling peptide RADA 16, modified by covalent immobilization of P substance, resulted in the recruitment of MSCs in the HLI region, followed by neovascularization (Kim et al. 2013). When loaded into a low-molecular-weight heparinprotamine complex, adipose-derived stem cells exhibited significant cell-cell interaction and improved cell viability, which may help to effectively rescue the limb from ischemia (Kishimoto et al. 2016).

The supplementation of growth factors along with cells is a conventional approach that aids in rapid tissue repair. Fibroblast growth factor-loaded gelatin hydrogel administered with adipose stem cells has shown mature blood vessel formation in the ischemic region of the hind limb. Transforming growth factor (TGF) $\beta 1$ was found to be upregulated in FGF-treated adipose stem cells, which indicated a therapeutic effect in HLI (Horikoshi-Ishihara et al. 2016). Injectable elastin-like polypeptide systems loaded with therapeutic plasmids for eNOS and interleukin (IL)-10 showed controlled dual gene delivery in the HLI region. The effective angiogenic response in combination with anti-inflammatory action was explored through CD31 (blood vessel marker) and CD68 (macrophage marker) immunostaining (Dash et 
al. 2015). Recently, Kwon et al. developed free radical-scavenging polymeric nanocarriers using $\mathrm{H}_{2} \mathrm{O}_{2}$-responsive polymer PVAX (polyoxalate containing vanillyl alcohol) (Kwon et al. 2016). The vanillyl alcohol released from the system effectively scavenges free radicals and imparts anti-inflammatory action. The binding affinity of heparin binding proteins towards alginate sulfate drives the formation of a self-assembled nanoparticle system. A combination of angiogenic growth factors, namely VEGF, TGF $\beta 1$, and PDGF-BB was favorably encapsulated within the nanoparticles due to the affinity binding nanoparticles with growth factors. The final formulation, when injected in an ischemic limb, improved angiogenesis and perfusion compared with a pristine alginate hydrogel (Ruvinov et al. 2016). The overall success of nanocarriers in the treatment of HLI has been well established at a pre-clinical level. Therefore, sufficient scope exists for the use of nanocarriers in clinical trials.

\section{The global picture of various agents in the treatment of limb ischemia}

The concept of angiogenesis was first described by Folkman (Folkman 1974) in 1974. Since then, therapeutic angiogenesis has been an area of active research. Numerous studies have been performed in this field, all of which have indicated a potential role for gene therapy in the management of cardiovascular disease. Despite the success of pre-clinical studies, researchers have been unsuccessful in replicating these results in humans. The reason for this failure is most likely multifactorial, including but not limited to the type of growth factors used in the study, improper study design, and selection of the patient population.

Numerous factors have been evaluated in both animal and human studies as potential treatment options for peripheral vascular disease [Figure 4]. Common growth factors include FGF, VEGF, HGF, IGF, transcription factors like HIF-1 $\alpha$ (Baffour et al. 1992; Shing et al. 
1984). There are several limitations to the above-mentioned studies. First, when used as a single factor, angiogenic growth factors show beneficial effects in animal trials. However, similar results have not been achieved in human studies. It is possible that single-agent gene therapy can improve local angiogenesis and arteriogenesis but is not sufficient to bring about a change in amputation rate and mortality, which are common endpoints in most phase II studies and beyond. One explanation for this may be that angiogenesis and arteriogenesis are multifactorial biological responses and many growth factors are involved in these complex processes from beginning to end. (Epstein et al. 2001) pointed out that at a therapeutic level, multiple factors or a combination of factors may be required to induce angiogenesis and arteriogenesis. For the combination of VEGF and Ang-1, VEGF induces the proliferation of endothelial cells and vascular tube formation whereas Ang-1 stimulates vascular budding and recruitment of periendothelial support cells for blood vessels stabilization. The absence of either VEGF or Ang-1 or their haphazard expression will not produce functional vessels. Similarly, Asahara et al. (Asahara et al. 1995) showed that the synergistic effects of the combination of VEGF and FGF are greater and more rapid than that of either VEGF or FGF alone. Thus, it is possible that a mixture of growth factors might be the solution to successful gene therapy in animal studies as well as human clinical trials.

Most clinical trials that have been performed to date have employed VEGF and FGF; however, the results from these trials were not as expected. Other factors, such as HGF and HIF$1 \alpha$, have shown promising results in animal studies and early clinical trials (Asahara et al. 1999; Lebherz et al. 2003; Yu et al. 2001). Indeed, HGF has shown beneficial effects in phase II clinical trials, whereas FGF and VEGF have failed to show efficacy (Bura et al. 2014; Marino et al. 2013). Is it possible that VEGF and FGF are merely non-specific components of the 
angiogenesis and arteriogenesis pathways and the primary controlling factors are either nonspecific or unknown? Further research is needed to answer this question.

The designs of clinical trials are based upon pre-clinical animal models. All animal models of HLI are based upon the ligation of external iliac and femoral arteries. After ligation, gene therapy is performed, and biological responses are monitored. Most animals have ischemia for a short duration of time before treatment is started. This scenario contrasts with actual clinical situations wherein the disease is often present for months or years before the patient seeks treatment. Can the results of animal studies with acute/semi-acute ischemia be extrapolated to human subjects who suffer from the chronic disease? Is it possible that chronic illness is associated with irreversible changes in the vasculature that are beyond the scope of "therapeutic angiogenesis"? Furthermore, PAD is an indicator of atherosclerosis, which itself is a clinical entity affecting almost all body systems. Most PAD patients have an unfavorable genetic background and negative influences from multiple co-morbidities, such as aging, smoking, alcohol, drugs, hyperlipidemia, hypertension, diabetes, obesity, acute coronary syndrome, and chronic kidney disease. Can a model of isolated HLI in a young healthy animal replicate the vascular environment of an aging, obese patient with all the above-mentioned morbidities? These are questions that need to be answered. Our current level of knowledge about angiogenesis and arteriogenesis suggests intriguing therapeutic possibilities, but it is still incomplete.

\section{Acknowledgements:}

This work was supported by Cardiovascular Research fund. We would like to thank Dr. Mahesh

Thirunavukkarasu during the preparation of this review article. 
https://mc06.manuscriptcentral.com/cjpp-pubs 


\section{References:}

Adam, D.J., Beard, J.D., Cleveland, T., Bell, J., Bradbury, A.W., Forbes, J.F., Fowkes, F.G., Gillepsie, I., Ruckley, C.V., Raab, G., and Storkey, H. 2005. Bypass versus angioplasty in severe ischaemia of the leg (BASIL): multicentre, randomised controlled trial. Lancet, 366(9501): 1925-1934. doi: 10.1016/s01406736(05)67704-5.

Adluri, R.S., Thirunavukkarasu, M., Dunna, N.R., Zhan, L., Oriowo, B., Takeda, K., Sanchez, J.A., Otani, H., Maulik, G., Fong, G.H., and Maulik, N. 2011a. Disruption of hypoxia-inducible transcription factor-prolyl hydroxylase domain-1 (PHD-1-/-) attenuates ex vivo myocardial ischemia/reperfusion injury through hypoxia-inducible factor-1alpha transcription factor and its target genes in mice. Antioxid. Redox Signal. 15(7): 1789-1797. doi: 10.1089/ars.2010.3769.

Adluri, R.S., Thirunavukkarasu, M., Zhan, L., Akita, Y., Samuel, S.M., Otani, H., Ho, Y.S., Maulik, G., and Maulik, N. 2011b. Thioredoxin 1 enhances neovascularization and reduces ventricular remodeling during chronic myocardial infarction: a study using thioredoxin 1 transgenic mice. J. Mol. Cell. Cardiol. 50(1): 239-247. doi: 10.1016/j.yjmcc.2010.11.002.

Anderson, J.L., Halperin, J.L., Albert, N.M., Bozkurt, B., Brindis, R.G., Curtis, L.H., DeMets, D., Guyton, R.A., Hochman, J.S., Kovacs, R.J., Ohman, E.M., Pressler, S.J., Sellke, F.W., and Shen, W.K. 2013. Management of patients with peripheral artery disease (compilation of 2005 and 2011 ACCF/AHA guideline recommendations): a report of the American College of Cardiology Foundation/American Heart Association Task Force on Practice Guidelines. Circulation, 127(13): 1425-1443. doi: 10.1161/CIR.0b013e31828b82aa.

Arner, E.S., and Holmgren, A. 2000. Physiological functions of thioredoxin and thioredoxin reductase. Eur. J. Biochem. 267(20): 6102-6109.

Arras, M., Ito, W.D., Scholz, D., Winkler, B., Schaper, J., and Schaper, W. 1998. Monocyte activation in angiogenesis and collateral growth in the rabbit hindlimb. J. Clin. Invest. 101(1): 40-50. doi: 10.1172/jci119877.

Asahara, T., Bauters, C., Zheng, L.P., Takeshita, S., Bunting, S., Ferrara, N., Symes, J.F., and Isner, J.M. 1995. Synergistic effect of vascular endothelial growth factor and basic fibroblast growth factor on angiogenesis in vivo. Circulation, 92(9 Suppl): li365-371.

Asahara, T., Murohara, T., Sullivan, A., Silver, M., van der Zee, R., Li, T., Witzenbichler, B., Schatteman, G., and Isner, J.M. 1997. Isolation of putative progenitor endothelial cells for angiogenesis. Science, 275(5302): 964-967.

Asahara, T., Takahashi, T., Masuda, H., Kalka, C., Chen, D., Iwaguro, H., Inai, Y., Silver, M., and Isner, J.M. 1999. VEGF contributes to postnatal neovascularization by mobilizing bone marrow-derived endothelial progenitor cells. EMBO J. 18(14): 3964-3972. doi: 10.1093/emboj/18.14.3964.

Baffour, R., Berman, J., Garb, J.L., Rhee, S.W., Kaufman, J., and Friedmann, P. 1992. Enhanced angiogenesis and growth of collaterals by in vivo administration of recombinant basic fibroblast growth 
factor in a rabbit model of acute lower limb ischemia: dose-response effect of basic fibroblast growth factor. J. Vasc. Surg. 16(2): 181-191.

Baumgartner, I., Chronos, N., Comerota, A., Henry, T., Pasquet, J.P., Finiels, F., Caron, A., Dedieu, J.F., Pilsudski, R., and Delaere, P. 2009. Local gene transfer and expression following intramuscular administration of FGF-1 plasmid DNA in patients with critical limb ischemia. Mol. Ther. 17(5): 914-921. doi: $10.1038 / \mathrm{mt} .2009 .24$.

Baumgartner, I., Pieczek, A., Manor, O., Blair, R., Kearney, M., Walsh, K., and Isner, J.M. 1998. Constitutive expression of phVEGF165 after intramuscular gene transfer promotes collateral vessel development in patients with critical limb ischemia. Circulation, 97(12): 1114-1123.

Baumgartner, I., Rauh, G., Pieczek, A., Wuensch, D., Magner, M., Kearney, M., Schainfeld, R., and Isner, J.M. 2000. Lower-extremity edema associated with gene transfer of naked DNA encoding vascular endothelial growth factor. Ann. Intern. Med. 132(11): 880-884.

Belch, J., Hiatt, W.R., Baumgartner, I., Driver, I.V., Nikol, S., Norgren, L., and Van Belle, E. 2011. Effect of fibroblast growth factor NV1FGF on amputation and death: a randomised placebo-controlled trial of gene therapy in critical limb ischaemia. Lancet, 377(9781): 1929-1937. doi: 10.1016/s01406736(11)60394-2.

Bentzon, J.F., Otsuka, F., Virmani, R., and Falk, E. 2014. Mechanisms of plaque formation and rupture. Circ. Res. 114(12): 1852-1866. doi: 10.1161/circresaha.114.302721.

Bertini, R., Howard, O.M., Dong, H.F., Oppenheim, J.J., Bizzarri, C., Sergi, R., Caselli, G., Pagliei, S., Romines, B., Wilshire, J.A., Mengozzi, M., Nakamura, H., Yodoi, J., Pekkari, K., Gurunath, R., Holmgren, A., Herzenberg, L.A., Herzenberg, L.A., and Ghezzi, P. 1999. Thioredoxin, a redox enzyme released in infection and inflammation, is a unique chemoattractant for neutrophils, monocytes, and T cells. J. Exp. Med. 189(11): 1783-1789.

Bottaro, D.P., Rubin, J.S., Faletto, D.L., Chan, A.M., Kmiecik, T.E., Vande Woude, G.F., and Aaronson, S.A. 1991. Identification of the hepatocyte growth factor receptor as the c-met proto-oncogene product. Science, 251(4995): 802-804.

Bura, A., Planat-Benard, V., Bourin, P., Silvestre, J.S., Gross, F., Grolleau, J.L., Saint-Lebese, B., Peyrafitte, J.A., Fleury, S., Gadelorge, M., Taurand, M., Dupuis-Coronas, S., Leobon, B., and Casteilla, L. 2014. Phase I trial: the use of autologous cultured adipose-derived stroma/stem cells to treat patients with nonrevascularizable critical limb ischemia. Cytotherapy, 16(2): 245-257. doi: 10.1016/j.jcyt.2013.11.011.

Bussolino, F., Di Renzo, M.F., Ziche, M., Bocchietto, E., Olivero, M., Naldini, L., Gaudino, G., Tamagnone, L., Coffer, A., and Comoglio, P.M. 1992. Hepatocyte growth factor is a potent angiogenic factor which stimulates endothelial cell motility and growth. J. Cell Biol. 119(3): 629-641.

Carmeliet, P. 2004. Manipulating angiogenesis in medicine. J. Intern. Med. 255(5): 538-561. doi: 10.1111/j.1365-2796.2003.01297.x.

Chai, N., Patel, Y., Jacobson, K., McMahon, J., McMahon, A., and Rappolee, D.A. 1998. FGF is an essential regulator of the fifth cell division in preimplantation mouse embryos. Dev. Biol. 198(1): 105-115. 
Chen, D.Y., Wei, H.J., Lin, K.J., Huang, C.C., Wang, C.C., Wu, C.T., Chao, K.T., Chen, K.J., Chang, Y., and Sung, H.W. 2013. Three-dimensional cell aggregates composed of HUVECs and cbMSCs for therapeutic neovascularization in a mouse model of hindlimb ischemia. Biomaterials, 34(8): 1995-2004. doi: 10.1016/j.biomaterials.2012.11.045.

Chen, J., Hui, S.T., Couto, F.M., Mungrue, I.N., Davis, D.B., Attie, A.D., Lusis, A.J., Davis, R.A., and Shalev, A. 2008. Thioredoxin-interacting protein deficiency induces $\mathrm{Akt} / \mathrm{Bcl}-\mathrm{xL}$ signaling and pancreatic beta-cell mass and protects against diabetes. FASEB J. 22(10): 3581-3594. doi: 10.1096/fj.08-111690.

Comerota, A.J., Throm, R.C., Miller, K.A., Henry, T., Chronos, N., Laird, J., Sequeira, R., Kent, C.K., Bacchetta, M., Goldman, C., Salenius, J.P., Schmieder, F.A., and Pilsudski, R. 2002. Naked plasmid DNA encoding fibroblast growth factor type 1 for the treatment of end-stage unreconstructible lower extremity ischemia: preliminary results of a phase I trial. J. Vasc. Surg. 35(5): 930-936.

Das, K.C. 2001. C-Jun NH2-terminal kinase-mediated redox-dependent degradation of IkappaB: role of thioredoxin in NF-kappaB activation. J. Biol. Chem. 276(7): 4662-4670. doi: 10.1074/jbc.M006206200.

Dash, B.C., Thomas, D., Monaghan, M., Carroll, O., Chen, X., Woodhouse, K., O'Brien, T., and Pandit, A. 2015. An injectable elastin-based gene delivery platform for dose-dependent modulation of angiogenesis and inflammation for critical limb ischemia. Biomaterials, 65: 126-139. doi: 10.1016/j.biomaterials.2015.06.037.

Deindl, E., Buschmann, I., Hoefer, I.E., Podzuweit, T., Boengler, K., Vogel, S., van Royen, N., Fernandez, B., and Schaper, W. 2001. Role of ischemia and of hypoxia-inducible genes in arteriogenesis after femoral artery occlusion in the rabbit. Circ. Res. 89(9): 779-786.

Dunn, L.L., Buckle, A., Simpson, P., Sieveking, D., Chow, R., Lim, P., and Ng, M. 2009. Rescue of diabetesrelated impairment of angiogenesis by gene silencing of thioredoxin-interacting protein. Circulation, 120(Suppl 18): S1142-S1142.

Dunn, L.L., Buckle, A.M., Cooke, J.P., and Ng, M.K. 2010. The emerging role of the thioredoxin system in angiogenesis. Arterioscler. Thromb. Vasc. Biol. 30(11): 2089-2098. doi: 10.1161/atvbaha.110.209643.

Epstein, S.E., Fuchs, S., Zhou, Y.F., Baffour, R., and Kornowski, R. 2001. Therapeutic interventions for enhancing collateral development by administration of growth factors: basic principles, early results and potential hazards. Cardiovasc. Res. 49(3): 532-542.

Ferrara, N., Carver-Moore, K., Chen, H., Dowd, M., Lu, L., O'Shea, K.S., Powell-Braxton, L., Hillan, K.J., and Moore, M.W. 1996. Heterozygous embryonic lethality induced by targeted inactivation of the VEGF gene. Nature, 380(6573): 439-442. doi: 10.1038/380439a0.

Ferrara, N., Chen, H., Davis-Smyth, T., Gerber, H.P., Nguyen, T.N., Peers, D., Chisholm, V., Hillan, K.J., and Schwall, R.H. 1998. Vascular endothelial growth factor is essential for corpus luteum angiogenesis. Nature medicine, 4(3): 336-340.

Ferrara, N., Gerber, H.P., and LeCouter, J. 2003. The biology of VEGF and its receptors. Nature medicine, 9(6): 669-676. doi: 10.1038/nm0603-669. 
Florkiewicz, R.Z., and Sommer, A. 1989. Human basic fibroblast growth factor gene encodes four polypeptides: three initiate translation from non-AUG codons. Proc. Natl. Acad. Sci. U.S.A. 86(11): 39783981.

Folkman, J. 1974. Tumor angiogenesis. Adv. Cancer Res.19(0): 331-358.

Galimi, F., Bagnara, G.P., Bonsi, L., Cottone, E., Follenzi, A., Simeone, A., and Comoglio, P.M. 1994. Hepatocyte growth factor induces proliferation and differentiation of multipotent and erythroid hemopoietic progenitors. J. Cell Biol. 127(6 Pt 1): 1743-1754.

Gerber, H.P., and Ferrara, N. 2003. The role of VEGF in normal and neoplastic hematopoiesis. J. Mol. Med. 81(1): 20-31. doi: 10.1007/s00109-002-0397-4.

Gerber, H.P., Vu, T.H., Ryan, A.M., Kowalski, J., Werb, Z., and Ferrara, N. 1999. VEGF couples hypertrophic cartilage remodeling, ossification and angiogenesis during endochondral bone formation. Nature medicine, 5(6): 623-628. doi: 10.1038/9467.

Gitay-Goren, H., Cohen, T., Tessler, S., Soker, S., Gengrinovitch, S., Rockwell, P., Klagsbrun, M., Levi, B.Z., and Neufeld, G. 1996. Selective binding of VEGF121 to one of the three vascular endothelial growth factor receptors of vascular endothelial cells. J. Biol. Chem. 271(10): 5519-5523.

Gu, C., Rodriguez, E.R., Reimert, D.V., Shu, T., Fritzsch, B., Richards, L.J., Kolodkin, A.L., and Ginty, D.D. 2003. Neuropilin-1 conveys semaphorin and VEGF signaling during neural and cardiovascular development. Developmental Cell, 5(1): 45-57.

Gupta, P.K., Chullikana, A., Parakh, R., Desai, S., Das, A., Gottipamula, S., Krishnamurthy, S., Anthony, N., Pherwani, A., and Majumdar, A.S. 2013. A double blind randomized placebo controlled phase I/II study assessing the safety and efficacy of allogeneic bone marrow derived mesenchymal stem cell in critical limb ischemia. J. Transl. Med.11: 143. doi: 10.1186/1479-5876-11-143.

Hardman, R.L., Jazaeri, O., Yi, J., Smith, M., and Gupta, R. 2014. Overview of classification systems in peripheral artery disease. Semin. Intervent. Radiol. 31(4): 378-388. doi: 10.1055/s-0034-1393976.

Hashimoto, T., Koyama, H., Miyata, T., Hosaka, A., Tabata, Y., Takato, T., and Nagawa, H. 2009. Selective and sustained delivery of basic fibroblast growth factor (bFGF) for treatment of peripheral arterial disease: results of a phase I trial. Eur. J. Vasc. Endovasc. Surg. 38(1): 71-75. doi: 10.1016/j.ejvs.2009.02.005.

Heil, M., Eitenmuller, I., Schmitz-Rixen, T., and Schaper, W. 2006. Arteriogenesis versus angiogenesis: similarities and differences. J. Cell. Mol. Med. 10(1): 45-55.

Henry, T.D., Cornerota, A., Chronos, N., Laird, J., Sequeira, R., Kottke, B., Kent, C., Salenius, J.-P., Pyle, M., and Pilsudski, R. 2002. FGF-1 gene therapy plasmid for patients with critical limb ischemia: final results. J. Am. Coll. Cardiol. 39: 9. 
Henry, T.D., Hirsch, A.T., Goldman, J., Wang, Y.L., Lips, D.L., McMillan, W.D., Duval, S., Biggs, T.A., and Keo, H.H. 2011. Safety of a non-viral plasmid-encoding dual isoforms of hepatocyte growth factor in critical limb ischemia patients: a phase I study. Gene Ther. 18(8): 788-794. doi: 10.1038/gt.2011.21.

Hirota, K., Murata, M., Sachi, Y., Nakamura, H., Takeuchi, J., Mori, K., and Yodoi, J. 1999. Distinct roles of thioredoxin in the cytoplasm and in the nucleus. A two-step mechanism of redox regulation of transcription factor NF-kappaB. J. Biol. Chem. 274(39): 27891-27897.

Horikoshi-Ishihara, H., Tobita, M., Tajima, S., Tanaka, R., Oshita, T., Tabata, Y., and Mizuno, H. 2016. Coadministration of adipose-derived stem cells and control-released basic fibroblast growth factor facilitates angiogenesis in a murine ischemic hind limb model. J. Vasc. Surg. 64(6): 1825 - 1834.e1. doi: 10.1016/j.jvs.2015.09.054.

Huang, P., Li, S., Han, M., Xiao, Z., Yang, R., and Han, Z.C. 2005. Autologous transplantation of granulocyte colony-stimulating factor-mobilized peripheral blood mononuclear cells improves critical limb ischemia in diabetes. Diabetes Care, 28(9): 2155-2160.

Imamura, T., Engleka, K., Zhan, X., Tokita, Y., Forough, R., Roeder, D., Jackson, A., Maier, J.A., Hla, T., and Maciag, T. 1990. Recovery of mitogenic activity of a growth factor mutant with a nuclear translocation sequence. Science, 249(4976): 1567-1570.

Isner, J.M., Pieczek, A., Schainfeld, R., Blair, R., Haley, L., Asahara, T., Rosenfield, K., Razvi, S., Walsh, K., and Symes, J.F. 1996. Clinical evidence of angiogenesis after arterial gene transfer of phVEGF165 in patient with ischaemic limb. Lancet, 348(9024): 370-374.

Isner, J.M., Walsh, K., Symes, J., Pieczek, A., Takeshita, S., Lowry, J., Rossow, S., Rosenfield, K., Weir, L., Brogi, E., and et al. 1995. Arterial gene therapy for therapeutic angiogenesis in patients with peripheral artery disease. Circulation, 91(11): 2687-2692.

Iwase, T., Nagaya, N., Fujii, T., Itoh, T., Murakami, S., Matsumoto, T., Kangawa, K., and Kitamura, S. 2005. Comparison of angiogenic potency between mesenchymal stem cells and mononuclear cells in a rat model of hindlimb ischemia. Cardiovasc. Res. 66(3): 543-551. doi: 10.1016/j.cardiores.2005.02.006.

Jude, E.B., Eleftheriadou, I., and Tentolouris, N. 2010. Peripheral arterial disease in diabetes--a review. Diabetic Med. 27(1): 4-14. doi: 10.1111/j.1464-5491.2009.02866.x.

Kalka, C., and Baumgartner, I. 2008. Gene and stem cell therapy in peripheral arterial occlusive disease. Vasc. Med. 13(2): 157-172. doi: 10.1177/1358863x08088616.

Kalka, C., Masuda, H., Takahashi, T., Kalka-Moll, W.M., Silver, M., Kearney, M., Li, T., Isner, J.M., and Asahara, T. 2000. Transplantation of ex vivo expanded endothelial progenitor cells for therapeutic neovascularization. Proc. Natl. Acad. Sci. U.S.A. 97(7): 3422-3427. doi: 10.1073/pnas.070046397.

Kan, M., Wang, F., Xu, J., Crabb, J.W., Hou, J., and McKeehan, W.L. 1993. An essential heparin-binding domain in the fibroblast growth factor receptor kinase. Science, 259(5103): 1918-1921.

Karkkainen, M.J., Makinen, T., and Alitalo, K. 2002. Lymphatic endothelium: a new frontier of metastasis research. Nature Cell Biol. 4(1): E2-5. doi: 10.1038/ncb0102-e2. 
Kawamoto, A., Katayama, M., Handa, N., Kinoshita, M., Takano, H., Horii, M., Sadamoto, K., Yokoyama, A., Yamanaka, T., Onodera, R., Kuroda, A., Baba, R., Kaneko, Y., Tsukie, T., Kurimoto, Y., Okada, Y., Kihara, Y., Morioka, S., Fukushima, M., and Asahara, T. 2009. Intramuscular transplantation of G-CSFmobilized CD34(+) cells in patients with critical limb ischemia: a phase I/Ila, multicenter, single-blinded, dose-escalation clinical trial. Stem cells (Dayton, Ohio), 27(11): 2857-2864. doi: 10.1002/stem.207.

Kawasaki, T., Kitsukawa, T., Bekku, Y., Matsuda, Y., Sanbo, M., Yagi, T., and Fujisawa, H. 1999. A requirement for neuropilin-1 in embryonic vessel formation. Development (Cambridge), 126(21): 48954902.

Kelly, B.D., Hackett, S.F., Hirota, K., Oshima, Y., Cai, Z., Berg-Dixon, S., Rowan, A., Yan, Z., Campochiaro, P.A., and Semenza, G.L. 2003. Cell type-specific regulation of angiogenic growth factor gene expression and induction of angiogenesis in nonischemic tissue by a constitutively active form of hypoxia-inducible factor 1. Circ. Res. 93(11): 1074-1081. doi: 10.1161/01.res.0000102937.50486.1b.

Kim, H.J., Jang, S.Y., Park, J.I., Byun, J., Kim, D.I., Do, Y.S., Kim, J.M., Kim, S., Kim, B.M., Kim, W.B., and Kim, D.K. 2004. Vascular endothelial growth factor-induced angiogenic gene therapy in patients with peripheral artery disease. Exp. Mol. Med. 36(4): 336-344. doi: 10.1038/emm.2004.44.

Kim, J.H., Jung, Y., Kim, B.S., and Kim, S.H. 2013. Stem cell recruitment and angiogenesis of neuropeptide substance $\mathrm{P}$ coupled with self-assembling peptide nanofiber in a mouse hind limb ischemia model. Biomaterials, 34(6): 1657-1668. doi: 10.1016/j.biomaterials.2012.11.008.

Kim, K.J., Li, B., Winer, J., Armanini, M., Gillett, N., Phillips, H.S., and Ferrara, N. 1993. Inhibition of vascular endothelial growth factor-induced angiogenesis suppresses tumour growth in vivo. Nature, 362(6423): 841-844. doi: 10.1038/362841a0.

Kinoshita, M., Fujita, Y., Katayama, M., Baba, R., Shibakawa, M., Yoshikawa, K., Katakami, N., Furukawa, Y., Tsukie, T., Nagano, T., Kurimoto, Y., Yamasaki, K., Handa, N., Okada, Y., Kuronaka, K., Nagata, Y., Matsubara, Y., Fukushima, M., Asahara, T., and Kawamoto, A. 2012. Long-term clinical outcome after intramuscular transplantation of granulocyte colony stimulating factor-mobilized CD34 positive cells in patients with critical limb ischemia. Atherosclerosis, 224(2): 440-445. doi: 10.1016/j.atherosclerosis.2012.07.031.

Kishimoto, S., Inoue, K., Nakamura, S., Hattori, H., Ishihara, M., Sakuma, M., Toyoda, S., Iwaguro, H., Taguchi, I., Inoue, T., and Yoshida, K. 2016. Low-molecular weight heparin protamine complex augmented the potential of adipose-derived stromal cells to ameliorate limb ischemia. Atherosclerosis, 249: 132-139. doi: 10.1016/j.atherosclerosis.2016.04.003.

Kondo, K., Shintani, S., Shibata, R., Murakami, H., Murakami, R., Imaizumi, M., Kitagawa, Y., and Murohara, T. 2009. Implantation of adipose-derived regenerative cells enhances ischemia-induced angiogenesis. Arterioscler. Thromb. Vasc. Biol. 29(1): 61-66. doi: 10.1161/atvbaha.108.166496.

Kumar, V.A., Liu, Q., Wickremasinghe, N.C., Shi, S., Cornwright, T.T., Deng, Y., Azares, A., Moore, A.N., Acevedo-Jake, A.M., Agudo, N.R., Pan, S., Woodside, D.G., Vanderslice, P., Willerson, J.T., Dixon, R.A., and Hartgerink, J.D. 2016. Treatment of hind limb ischemia using angiogenic peptide nanofibers. Biomaterials, 98: 113-119. doi: 10.1016/j.biomaterials.2016.04.032. 
Kusumanto, Y.H., van Weel, V., Mulder, N.H., Smit, A.J., van den Dungen, J.J., Hooymans, J.M., Sluiter, W.J., Tio, R.A., Quax, P.H., Gans, R.O., Dullaart, R.P., and Hospers, G.A. 2006. Treatment with intramuscular vascular endothelial growth factor gene compared with placebo for patients with diabetes mellitus and critical limb ischemia: a double-blind randomized trial. Human Gene Ther. 17(6): 683-691. doi: 10.1089/hum.2006.17.683.

Kwon, B., Kang, C., Kim, J., Yoo, D., Cho, B.R., Kang, P.M., and Lee, D. 2016. H2O2-responsive antioxidant polymeric nanoparticles as therapeutic agents for peripheral arterial disease. Int. J. Pharm. 511(2): 10221032. doi: 10.1016/j.ijpharm.2016.08.014.

Lebherz, C., von Degenfeld, G., Karl, A., Pfosser, A., Raake, P., Pachmayr, F., Scholz, D., Kupatt, C., and Boekstegers, P. 2003. Therapeutic angiogenesis/arteriogenesis in the chronic ischemic rabbit hindlimb: effect of venous basic fibroblast growth factor retroinfusion. Endothelium, 10(4-5): 257-265.

Lederman, R.J., Mendelsohn, F.O., Anderson, R.D., Saucedo, J.F., Tenaglia, A.N., Hermiller, J.B., Hillegass, W.B., Rocha-Singh, K., Moon, T.E., Whitehouse, M.J., and Annex, B.H. 2002. Therapeutic angiogenesis with recombinant fibroblast growth factor-2 for intermittent claudication (the TRAFFIC study): a randomised trial. Lancet, 359(9323): 2053-2058.

Li, X., Rong, Y., Zhang, M., Wang, X.L., LeMaire, S.A., Coselli, J.S., Zhang, Y., and Shen, Y.H. 2009. Upregulation of thioredoxin interacting protein (Txnip) by p38 MAPK and FOXO1 contributes to the impaired thioredoxin activity and increased ROS in glucose-treated endothelial cells. Biochem. Biophys. Res. Commun. 381(4): 660-665. doi: 10.1016/j.bbrc.2009.02.132.

Li, Y., Hazarika, S., Xie, D., Pippen, A.M., Kontos, C.D., and Annex, B.H. 2007. In mice with type 2 diabetes, a vascular endothelial growth factor (VEGF)-activating transcription factor modulates VEGF signaling and induces therapeutic angiogenesis after hindlimb ischemia. Diabetes, 56(3): 656-665. doi: 10.2337/db06-0999.

Lian, Q., Zhang, Y., Zhang, J., Zhang, H.K., Wu, X., Zhang, Y., Lam, F.F., Kang, S., Xia, J.C., Lai, W.H., Au, K.W., Chow, Y.Y., Siu, C.W., Lee, C.N., and Tse, H.F. 2010. Functional mesenchymal stem cells derived from human induced pluripotent stem cells attenuate limb ischemia in mice. Circulation, 121(9): 11131123. doi: 10.1161/circulationaha.109.898312.

Liu, Y., Xu, Y., Fang, F., Zhang, J., Guo, L., and Weng, Z. 2015. Therapeutic Efficacy of Stem Cell-based Therapy in Peripheral Arterial Disease: A Meta-Analysis. PloS One, 10(4): e0125032. doi: 10.1371/journal.pone.0125032.

Loo, B.M., Kreuger, J., Jalkanen, M., Lindahl, U., and Salmivirta, M. 2001. Binding of heparin/heparan sulfate to fibroblast growth factor receptor 4. J. Biol. Chem. 276(20): 16868-16876. doi: 10.1074/jbc.M011226200.

Losordo, D.W., and Dimmeler, S. 2004. Therapeutic angiogenesis and vasculogenesis for ischemic disease: part II: cell-based therapies. Circulation, 109(22): 2692-2697. doi: 10.1161/01.cir.0000128596.49339.05.

Losordo, D.W., Kibbe, M.R., Mendelsohn, F., Marston, W., Driver, V.R., Sharafuddin, M., Teodorescu, V., Wiechmann, B.N., Thompson, C., Kraiss, L., Carman, T., Dohad, S., Huang, P., Junge, C.E., Story, K., 
Weistroffer, T., Thorne, T.M., Millay, M., Runyon, J.P., and Schainfeld, R. 2012. A randomized, controlled pilot study of autologous CD34+ cell therapy for critical limb ischemia. Circ. Cardiovasc. Interv. 5(6): 821830. doi: 10.1161/circinterventions.112.968321.

Lu, D., Chen, B., Liang, Z., Deng, W., Jiang, Y., Li, S., Xu, J., Wu, Q., Zhang, Z., Xie, B., and Chen, S. 2011. Comparison of bone marrow mesenchymal stem cells with bone marrow-derived mononuclear cells for treatment of diabetic critical limb ischemia and foot ulcer: a double-blind, randomized, controlled trial. Diabetes Res. Clin. Pract. 92(1): 26-36. doi: 10.1016/j.diabres.2010.12.010.

Makinen, K., Manninen, H., Hedman, M., Matsi, P., Mussalo, H., Alhava, E., and Yla-Herttuala, S. 2002. Increased vascularity detected by digital subtraction angiography after VEGF gene transfer to human lower limb artery: a randomized, placebo-controlled, double-blinded phase II study. Mol. Ther. 6(1): 127-133. doi: 10.1006/mthe.2002.0638.

Marino, G., Moraci, M., Armenia, E., Orabona, C., Sergio, R., De Sena, G., Capuozzo, V., Barbarisi, M., Rosso, F., Giordano, G., lovino, F., and Barbarisi, A. 2013. Therapy with autologous adipose-derived regenerative cells for the care of chronic ulcer of lower limbs in patients with peripheral arterial disease. J. Surg. Res. 185(1): 36-44. doi: 10.1016/j.jss.2013.05.024.

Matsumoto, K., and Nakamura, T. 1992. Hepatocyte growth factor: molecular structure, roles in liver regeneration, and other biological functions. Crit. Rev. Oncogenesis, 3(1-2): 27-54.

Miranda-Vizuete, A., Ljung, J., Damdimopoulos, A.E., Gustafsson, J.A., Oko, R., Pelto-Huikko, M., and Spyrou, G. 2001. Characterization of Sptrx, a novel member of the thioredoxin family specifically expressed in human spermatozoa. J. Biol. Chem. 276(34): 31567-31574. doi: 10.1074/jbc.M101760200.

Miranville, A., Heeschen, C., Sengenes, C., Curat, C.A., Busse, R., and Bouloumie, A. 2004. Improvement of postnatal neovascularization by human adipose tissue-derived stem cells. Circulation, 110(3): 349355. doi: 10.1161/01.cir.0000135466.16823.d0.

Mohler, E.R., 3rd, Rajagopalan, S., Olin, J.W., Trachtenberg, J.D., Rasmussen, H., Pak, R., and Crystal, R.G. 2003. Adenoviral-mediated gene transfer of vascular endothelial growth factor in critical limb ischemia: safety results from a phase I trial. Vasc. Med. 8(1): 9-13.

Montesano, R., Matsumoto, K., Nakamura, T., and Orci, L. 1991. Identification of a fibroblast-derived epithelial morphogen as hepatocyte growth factor. Cell, 67(5): 901-908.

Morishita, R., Aoki, M., Hashiya, N., Makino, H., Yamasaki, K., Azuma, J., Sawa, Y., Matsuda, H., Kaneda, Y., and Ogihara, T. 2004. Safety evaluation of clinical gene therapy using hepatocyte growth factor to treat peripheral arterial disease. Hypertension, 44(2): 203-209. doi: 10.1161/01.HYP.0000136394.08900.ed.

Nakamura, T., Nawa, K., and Ichihara, A. 1984. Partial purification and characterization of hepatocyte growth factor from serum of hepatectomized rats. Biochem. Biophys. Res. Commun. 122(3): 1450-1459.

Neufeld, G., Cohen, T., Gengrinovitch, S., and Poltorak, Z. 1999. Vascular endothelial growth factor (VEGF) and its receptors. FASEB J. 13(1): 9-22. 
Nikol, S., Baumgartner, I., Van Belle, E., Diehm, C., Visona, A., Capogrossi, M.C., Ferreira-Maldent, N., Gallino, A., Graham Wyatt, M., Dinesh Wijesinghe, L., Fusari, M., Stephan, D., Emmerich, J., Pompilio, G., Vermassen, F., Pham, E., Grek, V., Coleman, M., and Meyer, F. 2008a. Therapeutic Angiogenesis With Intramuscular NV1FGF Improves Amputation-free Survival in Patients With Critical Limb Ischemia. Mol. Ther. 16(5): 972-978. doi: 10.1038/mt.2008.33.

Nikol, S., Baumgartner, I., Van Belle, E., Diehm, C., Visona, A., Capogrossi, M.C., Ferreira-Maldent, N., Gallino, A., Wyatt, M.G., Wijesinghe, L.D., Fusari, M., Stephan, D., Emmerich, J., Pompilio, G., Vermassen, F., Pham, E., Grek, V., Coleman, M., and Meyer, F. 2008b. Therapeutic angiogenesis with intramuscular NV1FGF improves amputation-free survival in patients with critical limb ischemia. Mol. Ther. 16(5): 972978. doi: $10.1038 / \mathrm{mt} .2008 .33$.

Nishimura, T., Utsunomiya, Y., Hoshikawa, M., Ohuchi, H., and Itoh, N. 1999. Structure and expression of a novel human FGF, FGF-19, expressed in the fetal brain. Biochim. Biophys. Acta, 1444(1): 148-151.

Nonn, L., Williams, R.R., Erickson, R.P., and Powis, G. 2003. The absence of mitochondrial thioredoxin 2 causes massive apoptosis, exencephaly, and early embryonic lethality in homozygous mice. Mol. Cell. Biol. 23(3): 916-922.

Nordberg, J., and Arner, E.S. 2001. Reactive oxygen species, antioxidants, and the mammalian thioredoxin system. Free Radic. Biol. Med. 31(11): 1287-1312.

Norgren, L., Hiatt, W.R., Dormandy, J.A., Nehler, M.R., Harris, K.A., Fowkes, F.G., Bell, K., Caporusso, J., Durand-Zaleski, I., Komori, K., Lammer, J., Liapis, C., Novo, S., Razavi, M., Robbs, J., Schaper, N., Shigematsu, H., Sapoval, M., White, C., White, J., Clement, D., Creager, M., Jaff, M., Mohler, E., 3rd, Rutherford, R.B., Sheehan, P., Sillesen, H., and Rosenfield, K. 2007. Inter-Society Consensus for the Management of Peripheral Arterial Disease (TASC II). Eur. J. Vasc. Endovasc. Surg. 33 Suppl 1: S1-75. doi: 10.1016/j.ejvs.2006.09.024.

Ouriel, K. 2001. Peripheral arterial disease. Lancet, 358(9289): 1257-1264. doi: 10.1016/s01406736(01)06351-6.

Ozturk, A., Kucukardali, Y., Tangi, F., Erikci, A., Uzun, G., Bashekim, C., Sen, H., Terekeci, H., Narin, Y., Ozyurt, M., Ozkan, S., Sayan, O., Rodop, O., Nalbant, S., Sildiroglu, O., Yalniz, F.F., Senkal, I.V., Sabuncu, H., and Oktenli, C. 2012. Therapeutical potential of autologous peripheral blood mononuclear cell transplantation in patients with type 2 diabetic critical limb ischemia. J. Diabetes Complications, 26(1): 29-33. doi: 10.1016/j.jdiacomp.2011.11.007.

Park, I.S., Chung, P.S., and Ahn, J.C. 2014. Enhanced angiogenic effect of adipose-derived stromal cell spheroid with low-level light therapy in hind limb ischemia mice. Biomaterials, 35(34): 9280-9289. doi: 10.1016/j.biomaterials.2014.07.061.

Park, J.E., Keller, G.A., and Ferrara, N. 1993. The vascular endothelial growth factor (VEGF) isoforms: differential deposition into the subepithelial extracellular matrix and bioactivity of extracellular matrixbound VEGF. Mol. Biol. Cell, 4(12): 1317-1326. 
Park, J.S., Yang, H.N., Yi, S.W., Kim, J.H., and Park, K.H. 2016. Neoangiogenesis of human mesenchymal stem cells transfected with peptide-loaded and gene-coated PLGA nanoparticles. Biomaterials, 76: 226237. doi: 10.1016/j.biomaterials.2015.10.062.

Partanen, J., Vainikka, S., Korhonen, J., Armstrong, E., and Alitalo, K. 1992. Diverse receptors for fibroblast growth factors. Prog. Growth Factor Res. 4(1): 69-83.

Pepper, M.S., Matsumoto, K., Nakamura, T., Orci, L., and Montesano, R. 1992. Hepatocyte growth factor increases urokinase-type plasminogen activator (u-PA) and u-PA receptor expression in Madin-Darby canine kidney epithelial cells. J. Biol. Chem. 267(28): 20493-20496.

Poltorak, Z., Cohen, T., Sivan, R., Kandelis, Y., Spira, G., Vlodavsky, I., Keshet, E., and Neufeld, G. 1997. VEGF145, a secreted vascular endothelial growth factor isoform that binds to extracellular matrix. J. Biol. Chem. 272(11): 7151-7158.

Powell, R.J., Dormandy, J., Simons, M., Morishita, R., and Annex, B.H. 2004. Therapeutic angiogenesis for critical limb ischemia: design of the hepatocyte growth factor therapeutic angiogenesis clinical trial. Vasc. Med. 9(3): 193-198.

Powell, R.J., Goodney, P., Mendelsohn, F.O., Moen, E.K., and Annex, B.H. 2010. Safety and efficacy of patient specific intramuscular injection of HGF plasmid gene therapy on limb perfusion and wound healing in patients with ischemic lower extremity ulceration: results of the HGF-0205 trial. J. Vasc. Surg. 52(6): 1525-1530. doi: 10.1016/j.jvs.2010.07.044.

Powell, R.J., Simons, M., Mendelsohn, F.O., Daniel, G., Henry, T.D., Koga, M., Morishita, R., and Annex, B.H. 2008. Results of a double-blind, placebo-controlled study to assess the safety of intramuscular injection of hepatocyte growth factor plasmid to improve limb perfusion in patients with critical limb ischemia. Circulation, 118(1): 58-65. doi: 10.1161/circulationaha.107.727347.

Powers, C.J., McLeskey, S.W., and Wellstein, A. 2000. Fibroblast growth factors, their receptors and signaling. Endocr.-Relat. Cancer,7(3): 165-197.

Pu, L.Q., Sniderman, A.D., Brassard, R., Lachapelle, K.J., Graham, A.M., Lisbona, R., and Symes, J.F. 1993. Enhanced revascularization of the ischemic limb by angiogenic therapy. Circulation, 88(1): 208-215. $\backslash$

Rajagopalan, S., Mohler, E., 3rd, Lederman, R.J., Saucedo, J., Mendelsohn, F.O., Olin, J., Blebea, J., Goldman, C., Trachtenberg, J.D., Pressler, M., Rasmussen, H., Annex, B.H., and Hirsch, A.T. $2003 a$. Regional Angiogenesis with Vascular Endothelial Growth Factor (VEGF) in peripheral arterial disease: Design of the RAVE trial. Am. Heart J. 145(6): 1114-1118. doi: 10.1016/s0002-8703(03)00102-9.

Rajagopalan, S., Mohler, E.R., 3rd, Lederman, R.J., Mendelsohn, F.O., Saucedo, J.F., Goldman, C.K., Blebea, J., Macko, J., Kessler, P.D., Rasmussen, H.S., and Annex, B.H. 2003b. Regional angiogenesis with vascular endothelial growth factor in peripheral arterial disease: a phase II randomized, double-blind, controlled study of adenoviral delivery of vascular endothelial growth factor 121 in patients with disabling intermittent claudication. Circulation, 108(16): 1933-1938. doi: 10.1161/01.cir.0000093398.16124.29. 
Rajagopalan, S., Olin, J., Deitcher, S., Pieczek, A., Laird, J., Grossman, P.M., Goldman, C.K., McEllin, K., Kelly, R., and Chronos, N. 2007. Use of a constitutively active hypoxia-inducible factor-1alpha transgene as a therapeutic strategy in no-option critical limb ischemia patients: phase I dose-escalation experience. Circulation, 115(10): 1234-1243. doi: 10.1161/circulationaha.106.607994.

Rajagopalan, S., Olin, J.W., Young, S., Erikson, M., Grossman, P.M., Mendelsohn, F.O., Regensteiner, J.G., Hiatt, W.R., and Annex, B.H. 2004. Design of the Del-1 for therapeutic angiogenesis trial (DELTA-1), a phase II multicenter, double-blind, placebo-controlled trial of VLTS-589 in subjects with intermittent claudication secondary to peripheral arterial disease. Human Gene Ther. 15(6): 619-624. doi: 10.1089/104303404323142060.

Rishi, M.T., Selvaraju, V., Thirunavukkarasu, M., Shaikh, I.A., Takeda, K., Fong, G.H., Palesty, J.A., Sanchez, J.A., and Maulik, N. 2015. Deletion of prolyl hydroxylase domain proteins (PHD1, PHD3) stabilizes hypoxia inducible factor-1 alpha, promotes neovascularization, and improves perfusion in a murine model of hind-limb ischemia. Microvasc. Res. 97: 181-188. doi: 10.1016/j.mvr.2014.10.009.

Roger, V.L., Go, A.S., Lloyd-Jones, D.M., Adams, R.J., Berry, J.D., Brown, T.M., Carnethon, M.R., Dai, S., de Simone, G., Ford, E.S., Fox, C.S., Fullerton, H.J., Gillespie, C., Greenlund, K.J., Hailpern, S.M., Heit, J.A., Ho, P.M., Howard, V.J., Kissela, B.M., Kittner, S.J., Lackland, D.T., Lichtman, J.H., Lisabeth, L.D., Makuc, D.M., Marcus, G.M., Marelli, A., Matchar, D.B., McDermott, M.M., Meigs, J.B., Moy, C.S., Mozaffarian, D., Mussolino, M.E., Nichol, G., Paynter, N.P., Rosamond, W.D., Sorlie, P.D., Stafford, R.S., Turan, T.N., Turner, M.B., Wong, N.D., and Wylie-Rosett, J. 2011. Heart disease and stroke statistics--2011 update: a report from the American Heart Association. Circulation, 123(4): e18-e209. doi: 10.1161/CIR.0b013e3182009701.

Rufaihah, A.J., Huang, N.F., Jame, S., Lee, J.C., Nguyen, H.N., Byers, B., De, A., Okogbaa, J., Rollins, M., Reijo-Pera, R., Gambhir, S.S., and Cooke, J.P. 2011. Endothelial cells derived from human iPSCS increase capillary density and improve perfusion in a mouse model of peripheral arterial disease. Arterioscler. Thromb. Vasc. Biol. 31(11): e72-79. doi: 10.1161/atvbaha.111.230938.

Ruvinov, E., Freeman, I., Fredo, R., and Cohen, S. 2016. Spontaneous Coassembly of Biologically Active Nanoparticles via Affinity Binding of Heparin-Binding Proteins to Alginate-Sulfate. Nano Letters, 16(2): 883-888. doi: 10.1021/acs.nanolett.5b03598.

Salceda, S., and Caro, J. 1997. Hypoxia-inducible factor 1alpha (HIF-1alpha) protein is rapidly degraded by the ubiquitin-proteasome system under normoxic conditions. Its stabilization by hypoxia depends on redox-induced changes. J. Biol. Chem. 272(36): 22642-22647.

Samuel, S.M., Thirunavukkarasu, M., Penumathsa, S.V., Koneru, S., Zhan, L., Maulik, G., Sudhakaran, P.R., and Maulik, N. 2010. Thioredoxin-1 gene therapy enhances angiogenic signaling and reduces ventricular remodeling in infarcted myocardium of diabetic rats. Circulation, 121(10): 1244-1255. doi: 10.1161/circulationaha.109.872481.

Saxena, G., Chen, J., and Shalev, A. 2010. Intracellular shuttling and mitochondrial function of thioredoxin-interacting protein. J. Biol. Chem. 285(6): 3997-4005. doi: 10.1074/jbc.M109.034421.

Selvaraju, V., Parinandi, N.L., Adluri, R.S., Goldman, J.W., Hussain, N., Sanchez, J.A., and Maulik, N. 2014. Molecular mechanisms of action and therapeutic uses of pharmacological inhibitors of HIF-prolyl 4- 
hydroxylases for treatment of ischemic diseases. Antioxid. Redox. Signal. 20(16): 2631-2665. doi: 10.1089/ars.2013.5186.

Semenza, G.L. 2003. Targeting HIF-1 for cancer therapy. Nature Rev. Cancer, 3(10): 721-732. doi: $10.1038 /$ nrc1187.

Semenza, G.L. 2007. Vasculogenesis, angiogenesis, and arteriogenesis: mechanisms of blood vessel formation and remodeling. J. Cell. Biochem. 102(4): 840-847. doi: 10.1002/jcb.21523.

Shigematsu, H., Yasuda, K., Iwai, T., Sasajima, T., Ishimaru, S., Ohashi, Y., Yamaguchi, T., Ogihara, T., and Morishita, R. 2010. Randomized, double-blind, placebo-controlled clinical trial of hepatocyte growth factor plasmid for critical limb ischemia. Gene Ther. 17(9): 1152-1161. doi: 10.1038/gt.2010.51

Shing, Y., Folkman, J., Sullivan, R., Butterfield, C., Murray, J., and Klagsbrun, M. 1984. Heparin affinity: purification of a tumor-derived capillary endothelial cell growth factor. Science, 223(4642): 1296-1299.

Shintani, S., Murohara, T., Ikeda, H., Ueno, T., Sasaki, K., Duan, J., and Imaizumi, T. 2001. Augmentation of postnatal neovascularization with autologous bone marrow transplantation. Circulation, 103(6): 897903.

Shyu, K.G., Chang, H., Wang, B.W., and Kuan, P. 2003. Intramuscular vascular endothelial growth factor gene therapy in patients with chronic critical leg ischemia. Am. J. Med. 114(2): 85-92.

Silvagno, F., Follenzi, A., Arese, M., Prat, M., Giraudo, E., Gaudino, G., Camussi, G., Comoglio, P.M., and Bussolino, F. 1995. In vivo activation of met tyrosine kinase by heterodimeric hepatocyte growth factor molecule promotes angiogenesis. Arterioscler. Thromb. Vasc. Biol. 15(11): 1857-1865.

Simovic, D., Isner, J.M., Ropper, A.H., Pieczek, A., and Weinberg, D.H. 2001. Improvement in chronic ischemic neuropathy after intramuscular phVEGF165 gene transfer in patients with critical limb ischemia. Arch. Neurol. 58(5): 761-768.

Soker, S., Fidder, H., Neufeld, G., and Klagsbrun, M. 1996. Characterization of novel vascular endothelial growth factor (VEGF) receptors on tumor cells that bind VEGF165 via its exon 7-encoded domain. J. Biol. Chem. 271(10): 5761-5767.

Soker, S., Takashima, S., Miao, H.Q., Neufeld, G., and Klagsbrun, M. 1998. Neuropilin-1 is expressed by endothelial and tumor cells as an isoform-specific receptor for vascular endothelial growth factor. Cell, 92(6): 735-745.

Spivak-Kroizman, T., Lemmon, M.A., Dikic, I., Ladbury, J.E., Pinchasi, D., Huang, J., Jaye, M., Crumley, G., Schlessinger, J., and Lax, I. 1994. Heparin-induced oligomerization of FGF molecules is responsible for FGF receptor dimerization, activation, and cell proliferation. Cell, 79(6): 1015-1024.

Takeshita, S., Pu, L.Q., Stein, L.A., Sniderman, A.D., Bunting, S., Ferrara, N., Isner, J.M., and Symes, J.F. 1994. Intramuscular administration of vascular endothelial growth factor induces dose-dependent collateral artery augmentation in a rabbit model of chronic limb ischemia. Circulation, 90(5 Pt 2): li228234. 
Tanaka, T., Hosoi, F., Yamaguchi-Iwai, Y., Nakamura, H., Masutani, H., Ueda, S., Nishiyama, A., Takeda, S., Wada, H., Spyrou, G., and Yodoi, J. 2002. Thioredoxin-2 (TRX-2) is an essential gene regulating mitochondria-dependent apoptosis. EMBO J. 21(7): 1695-1703. doi: 10.1093/emboj/21.7.1695.

Taniyama, Y., Morishita, R., Aoki, M., Nakagami, H., Yamamoto, K., Yamazaki, K., Matsumoto, K., Nakamura, T., Kaneda, Y., and Ogihara, T. 2001. Therapeutic angiogenesis induced by human hepatocyte growth factor gene in rat and rabbit hindlimb ischemia models: preclinical study for treatment of peripheral arterial disease. Gene Ther. 8(3): 181-189. doi: 10.1038/sj.gt.3301379.

Tateishi-Yuyama, E., Matsubara, H., Murohara, T., Ikeda, U., Shintani, S., Masaki, H., Amano, K., Kishimoto, Y., Yoshimoto, K., Akashi, H., Shimada, K., Iwasaka, T., and Imaizumi, T. 2002. Therapeutic angiogenesis for patients with limb ischaemia by autologous transplantation of bone-marrow cells: a pilot study and a randomised controlled trial. Lancet, 360(9331): 427-435. doi: 10.1016/s01406736(02)09670-8.

Tepper, O.M., Capla, J.M., Galiano, R.D., Ceradini, D.J., Callaghan, M.J., Kleinman, M.E., and Gurtner, G.C. 2005. Adult vasculogenesis occurs through in situ recruitment, proliferation, and tubulization of circulating bone marrow-derived cells. Blood, 105(3): 1068-1077. doi: 10.1182/blood-2004-03-1051.

Teraa, M., Conte, M.S., Moll, F.L., and Verhaar, M.C. 2016. Critical Limb Ischemia: Current Trends and Future Directions. J. Am. Heart Assoc. 5(2). doi: 10.1161/jaha.115.002938.

Teraa, M., Sprengers, R.W., Schutgens, R.E., Slaper-Cortenbach, I.C., van der Graaf, Y., Algra, A., van der Tweel, I., Doevendans, P.A., Mali, W.P., Moll, F.L., and Verhaar, M.C. 2015. Effect of repetitive intraarterial infusion of bone marrow mononuclear cells in patients with no-option limb ischemia: the randomized, double-blind, placebo-controlled Rejuvenating Endothelial Progenitor Cells via Transcutaneous Intra-arterial Supplementation (JUVENTAS) trial. Circulation, 131(10): 851-860. doi: 10.1161/circulationaha.114.012913.

Thirunavukkarasu, M., Shaikh, I.A., Selvaraju, V., Palesty, J.A., and Maulik, N. 2014. Thereapeutic Angiogenesis Induced by Human Trx-1 Gene in Mice Hind Limb Ischemia Model: Preclinical Study for Treatment of Peripheral Artery Disease. Circulation, 130(Suppl 2): A17955-A17955.

van Bruggen, N., Thibodeaux, H., Palmer, J.T., Lee, W.P., Fu, L., Cairns, B., Tumas, D., Gerlai, R., Williams, S.P., van Lookeren Campagne, M., and Ferrara, N. 1999. VEGF antagonism reduces edema formation and tissue damage after ischemia/reperfusion injury in the mouse brain. J. Clin. Invest. 104(11): 1613-1620. doi: $10.1172 /$ jci8218.

Waltenberger, J., Mayr, U., Pentz, S., and Hombach, V. 1996. Functional upregulation of the vascular endothelial growth factor receptor KDR by hypoxia. Circulation, 94(7): 1647-1654.

Walter, D.H., Krankenberg, H., Balzer, J.O., Kalka, C., Baumgartner, I., Schluter, M., Tonn, T., Seeger, F., Dimmeler, S., Lindhoff-Last, E., and Zeiher, A.M. 2011. Intraarterial administration of bone marrow mononuclear cells in patients with critical limb ischemia: a randomized-start, placebo-controlled pilot trial (PROVASA). Circ. Cardiovasc. Interv. 4(1): 26-37. doi: 10.1161/circinterventions.110.958348. 
Wang, G.L., Jiang, B.H., Rue, E.A., and Semenza, G.L. 1995. Hypoxia-inducible factor 1 is a basic-helixloop-helix-PAS heterodimer regulated by cellular 02 tension. Proc. Natl. Acad. Sci. U.S.A. 92(12): 55105514.

Wang, G.L., and Semenza, G.L. 1995. Purification and characterization of hypoxia-inducible factor 1. J. Biol. Chem. 270(3): 1230-1237.

Weitz, J.I., Byrne, J., Clagett, G.P., Farkouh, M.E., Porter, J.M., Sackett, D.L., Strandness, D.E., Jr., and Taylor, L.M. 1996. Diagnosis and treatment of chronic arterial insufficiency of the lower extremities: a critical review. Circulation, 94(11): 3026-3049.

Welsh, S.J., Williams, R.R., Birmingham, A., Newman, D.J., Kirkpatrick, D.L., and Powis, G. 2003. The thioredoxin redox inhibitors 1-methylpropyl 2-imidazolyl disulfide and pleurotin inhibit hypoxia-induced factor 1alpha and vascular endothelial growth factor formation. Mol. Cancer Ther. 2(3): 235-243.

Wung, B.S., Cheng, J.J., Chao, Y.J., Lin, J., Shyy, Y.J., and Wang, D.L. 1996. Cyclical strain increases monocyte chemotactic protein-1 secretion in human endothelial cells. Am. J. Physiol. 270(4 Pt 2): H1462-1468.

Yang, H.N., Park, J.S., Woo, D.G., Jeon, S.Y., and Park, K.H. 2012. Transfection of VEGF(165) genes into endothelial progenitor cells and in vivo imaging using quantum dots in an ischemia hind limb model. Biomaterials, 33(33): 8670-8684. doi: 10.1016/j.biomaterials.2012.08.012.

Yoo, C.H., Na, H.J., Lee, D.S., Heo, S.C., An, Y., Cha, J., Choi, C., Kim, J.H., Park, J.C., and Cho, Y.S. 2013. Endothelial progenitor cells from human dental pulp-derived iPS cells as a therapeutic target for ischemic vascular diseases. Biomaterials, 34(33): 8149-8160. doi: 10.1016/j.biomaterials.2013.07.001.

Yoshihara, E., Masaki, S., Matsuo, Y., Chen, Z., Tian, H., and Yodoi, J. 2014. Thioredoxin/Txnip: redoxisome, as a redox switch for the pathogenesis of diseases. Front. Immunol. 4: 514. doi: 10.3389/fimmu.2013.00514.

Yu, F., White, S.B., Zhao, Q., and Lee, F.S. 2001. HIF-1alpha binding to VHL is regulated by stimulussensitive proline hydroxylation. Proc. Natl. Acad. Sci. U.S.A. 98(17): 9630-9635. doi: $10.1073 /$ pnas.181341498.

Zhang, J., Wang, G., Mao, D., Han, A., Xiao, N., Qi, X., Ding, D., and Kong, D. 2015. Targeted <i>in vivo</i> imaging of mouse hindlimb ischemia using fluorescent gelatin nanoparticles. J. Nanomaterials, 2015: 66. doi: 10.1155/2015/704817. 


\section{Figure Legends}

Figure 1: Schematic illustration showing trimodal therapeutic strategies using growth factors, cells, and nanocarriers to rescue the hind limb from the ischemic disorder.

Figure 2: A signaling cascade demonstrating the Thioredoxin-1 mediated effective rescue of angiogenesis during pathological conditions.

Figure 3: Comparison of laser Doppler perfusion images (LDPIs) of wild type (WT), prolyl hydroxylase domain $\left(\mathrm{PHD}^{-/}\right)$, and $\mathrm{PHD}^{-/-}$mice after right femoral artery ligation with representative LDIs from different groups. Laser Doppler imaging was used to take baseline preoperative and post-operative images on days $0,3,7,14,21$ and 28 . Red indicates maximum perfusion, whereas black indicates minimum perfusion. $\mathrm{PHD}^{-/-}$and $\mathrm{PHD}^{-/-}$mice showed significantly increased perfusion ratios as compared with WT mice over the course of a 28-day post-operative period. Figure and legend adapted from (Rishi et al. 2015).

Figure 4: Schematic representation of a list of growth factors, their corresponding receptors, and redox active intracellular proteins involved in endothelial cell fate determination. 


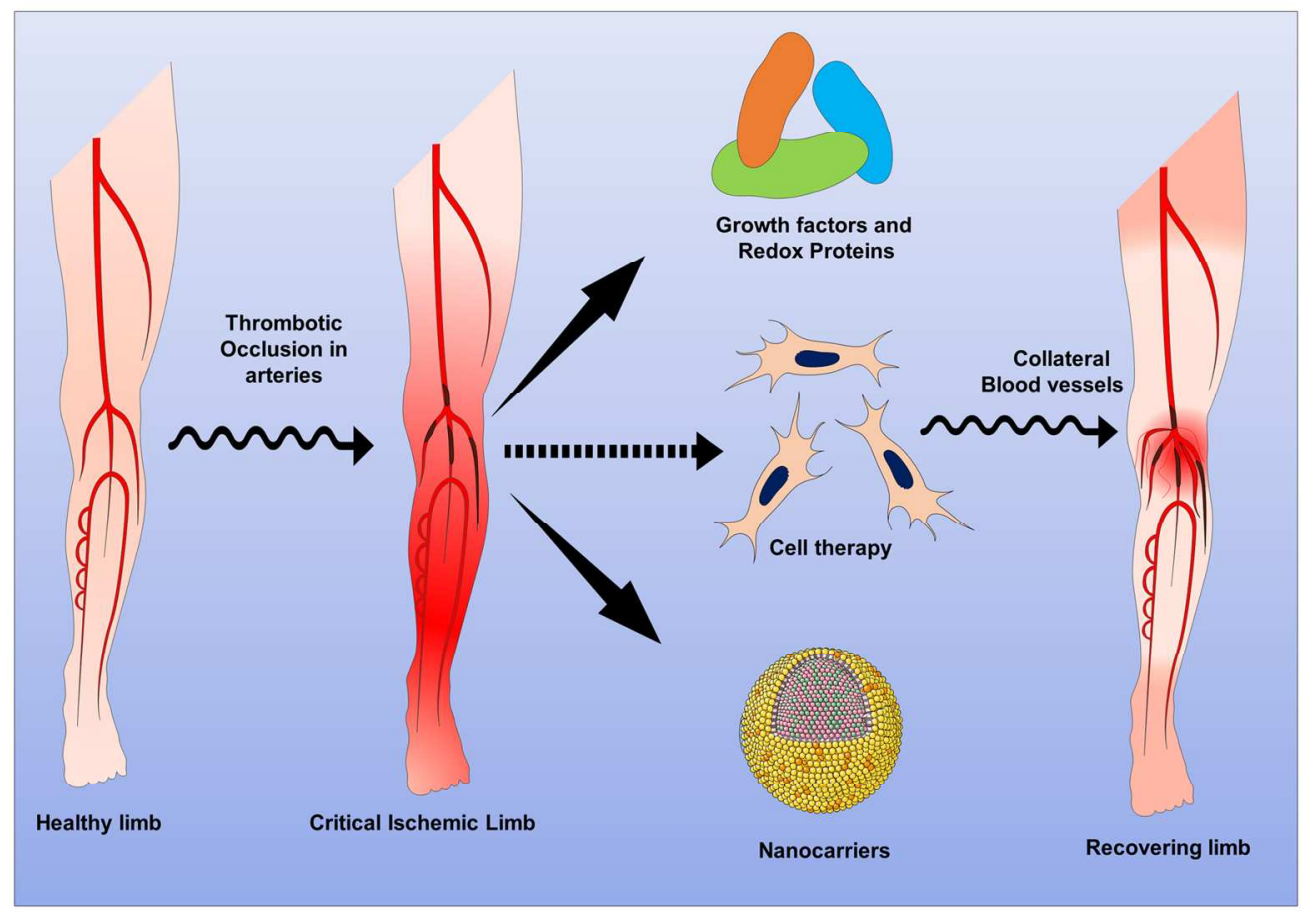

$152 \times 106 \mathrm{~mm}(300 \times 300$ DPI $)$ 


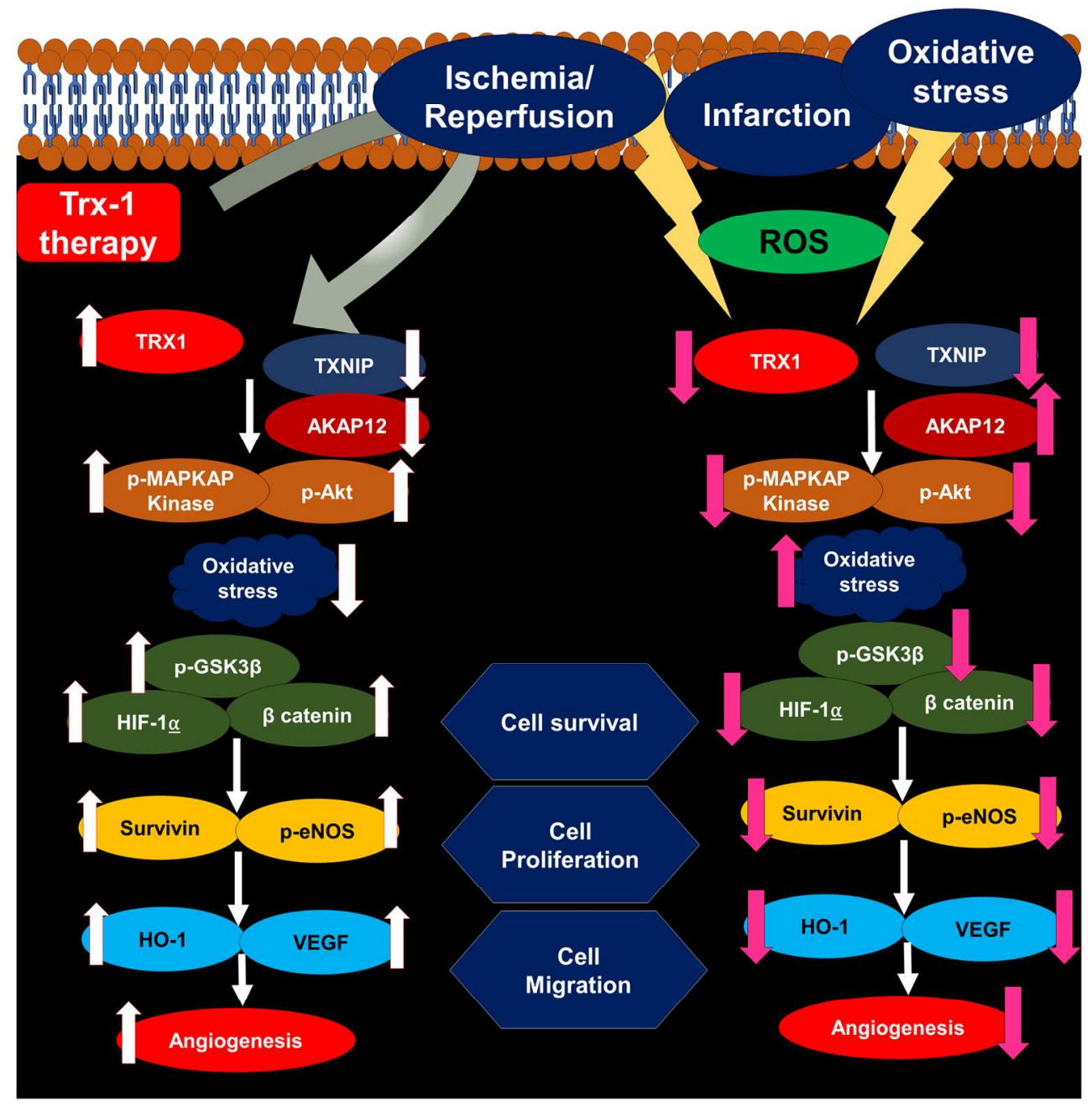

$152 \times 155 \mathrm{~mm}(300 \times 300$ DPI $)$ 


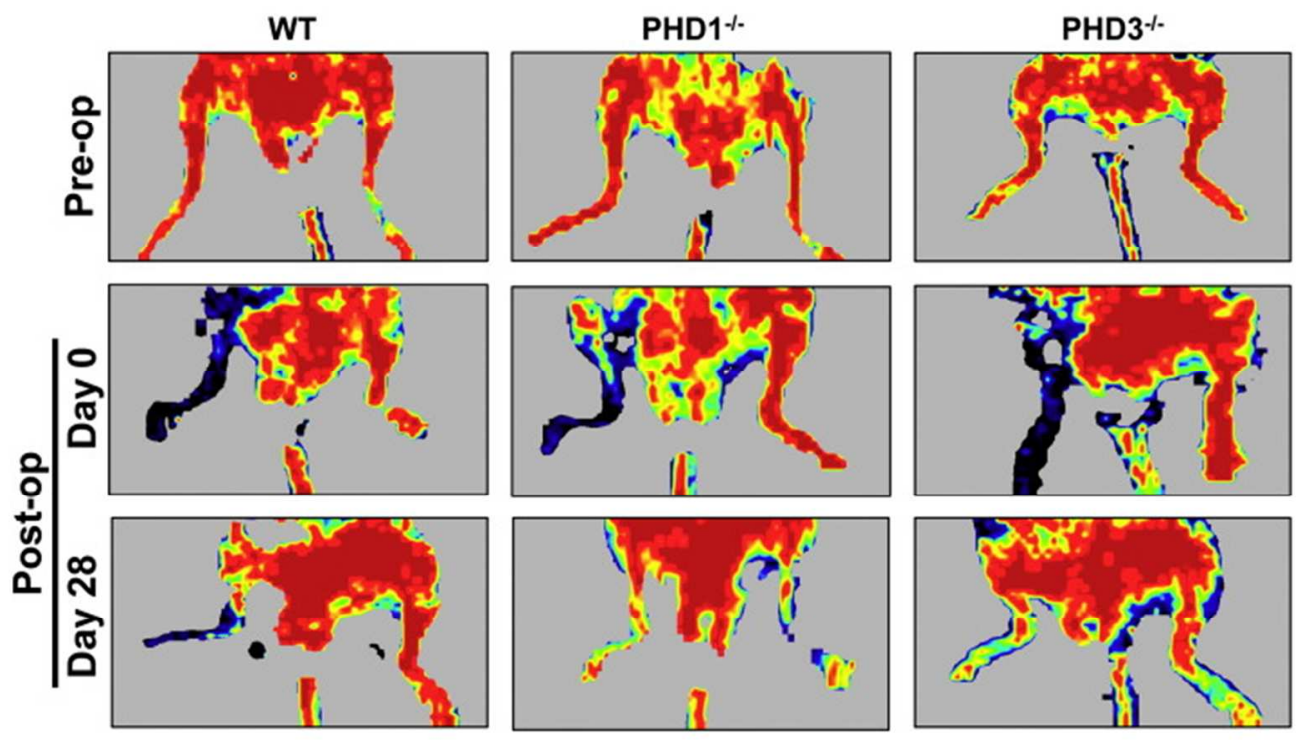

$152 \times 86 \mathrm{~mm}(300 \times 300$ DPI $)$ 


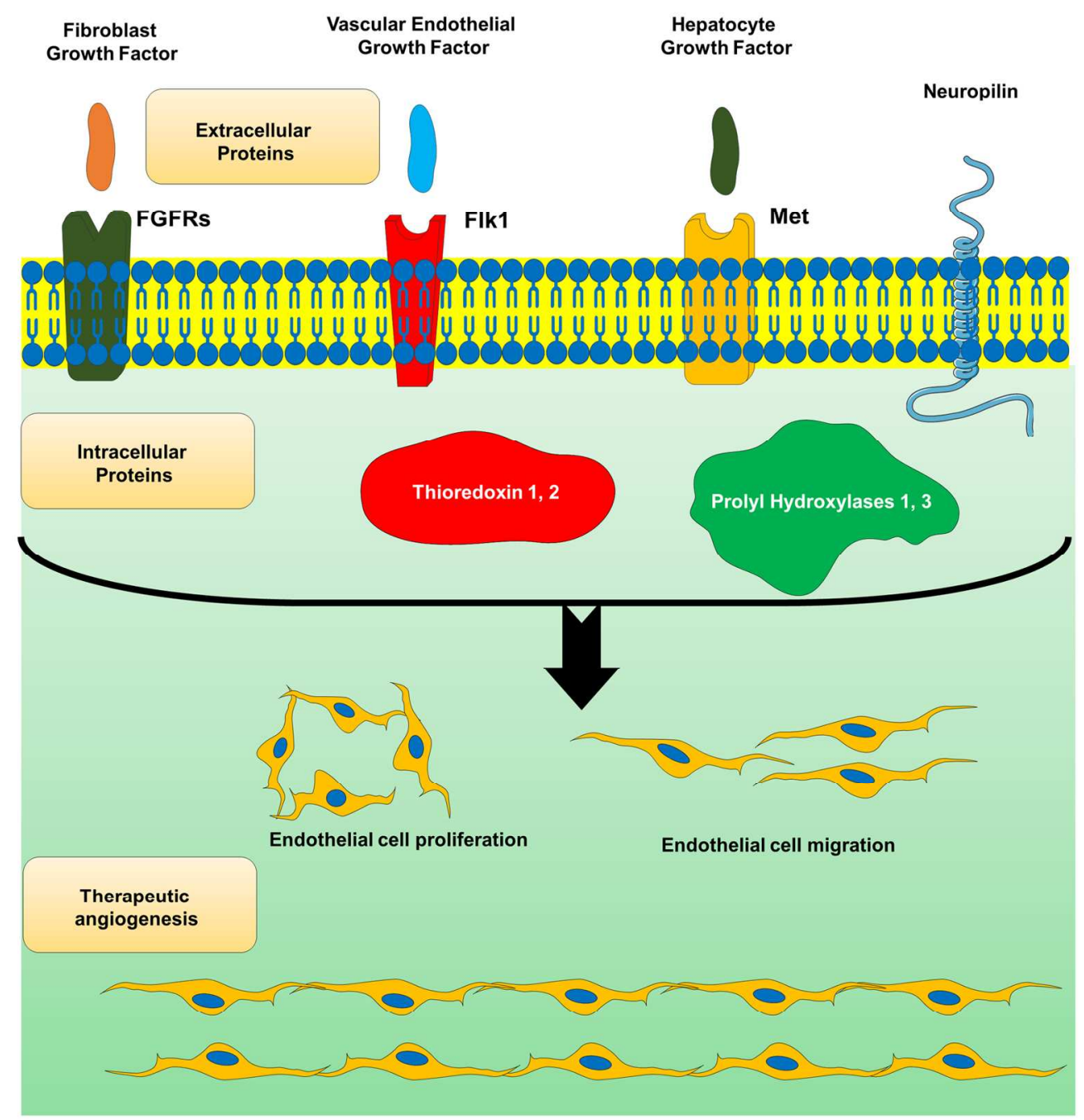

$152 \times 161 \mathrm{~mm}(300 \times 300 \mathrm{DPI})$ 